(Final version)

\title{
Openness, Knowledge, Innovation and Growth in UK Business Services
}

\author{
James H Love \\ Birmingham Business School, University of Birmingham, \\ Birmingham, B15 2TT. \\ E-Mail: j.h.love@bham.ac.uk \\ Stephen Roper \\ Centre for Small and Medium Sized Enterprises, Warwick Business School, \\ University of Warwick, Coventry, CV4 7AL. \\ E-Mail: stephen.roper@wbs.ac.uk \\ John R Bryson \\ School of Geography, Earth and Environmental Sciences, \\ University of Birmingham, Birmingham, B15 2TT. \\ E-mail: j.r.bryson@bham.ac.uk
}

\begin{abstract}
We explore the causal links between service firms' knowledge investments, their innovation outputs and business growth based on a bespoke survey of around $1100 \mathrm{UK}$ service businesses. We combine the activity based approach of the innovation value chain with firms' external links at each stage of the innovation process. This introduces the notion of 'encoding' relationships through which learning improves the effectiveness of firms' innovation processes. Our econometric results emphasise the importance of openness in the initial, exploratory phase of the innovation process and the significance of team working in later stages of the process. In-house design capacity is strongly linked to a firm's ability to absorb external knowledge for innovation. Business growth is related directly to both the extent of firms' service innovation as well as the diversity of innovation reflecting marketing, strategic and business process change. Links to customers are important in the exploratory stage of the innovation process, but encoding linkages with private and public research organisations are more important in developing innovation outputs.
\end{abstract}

\section{Acknowledgements}

The data on which this paper was based was collected as part of the UK Innovation Index project sponsored by the National Endowment for Science, Technology and the Arts (NESTA). Dr Chantal Hales (University of Birmingham) was also part of the original project team. Data analysis was carried out as part of a project funded by the ESRC (Award RES-062-23-2767). We are grateful for the constructive comments of Daniele Archibugi, Keld Laursen and participants at the conference on 'The role of business services for innovation, internationalisation and growth', University of Rome 'La Sapienza', December 2010. Valuable comments were also received from two referees.

Key words: open innovation, services, innovation value chain, encoding linkages 


\section{Introduction}

Innovation - broadly defined as the commercial application of new knowledge - has been recognised both in the UK and internationally as one of the key drivers of growth and productivity (Treasury 2000; Guellec and van Pottelsberghe 2004). Reflecting ongoing structural change, however, it is innovation in the service industries which is attracting increasing attention (Gallouj and Djellal, 2010). Service innovation may, of course, have direct benefits by promoting services growth, productivity (Cainelli et al 2006; Mansury and Love 2008) and exports (Gourlay et et al 2005; Blind and Jungmittag 2004; Bryson, 2007). Indirect benefits may also result from service innovation, however, due to the enabling role of the service sector and its contribution to supporting innovation and growth in other industries and the public sector (Muller and Zenker 2001; Wood 2005; Czarnitzki and Spielkamp 2003; OECD 2007; Baker, 2007; Bryson, 2010). These types of indirect benefit may be particularly evident in the type of knowledge intensive business services considered here which can act as 'carriers of knowledge' in their role as providers of intermediate inputs into the activities of their clients (Bessant and Rush 1995; Rubalcaba and Kox, 2007; den Hertog 2010).

One of the issues in the literature is the recognition that the process of innovation may be different in services; for example, the traditional distinction between product and process innovation may be less meaningful in services. Howells and Tether (2004) suggest a more meaningful distinction may be between inward-looking and outwardlooking innovation activity, where outward-looking innovation is principally concerned with the firm's interaction with external actors, notably customers. This is supported by the view that the use of external sources may be particularly important for the service sector (Hipp 1999; Potts and Mandeville 2007; Tether and Tajar 2008; Hipp 2010; Chesbrough and Davies, 2010). In a comparison of the innovation process of manufacturing and service firms, Tether (2005) finds that while manufacturers are more likely to innovate through using in-house $R \& D$ and collaborations with universities and research institutes, service firms are more likely to make use of collaborations with customers and suppliers, especially where they have an organisational orientation to their innovation activities. Leiponen (2005) finds support for this view. In a survey of Finnish business service firms, she finds that external sourcing of knowledge, especially 
from customers and competitors, positively affected both the probability and extent of innovation, while in-house R\&D intensity had no discernible effect. And in a study of US business services firms, Mansury and Love (2008) find that external linkages have an overwhelmingly positive effect on (innovator) firm performance, regardless of whether innovation is measured as a discrete or continuous variable, and regardless of the level of innovation considered. Similar results are found for a sample of service sector firms in Northern Ireland (Love e al 2010).

This suggests that the role of external 'openness' through partners and linkages is of particular importance in service sector innovation, and that a clearer understanding of how these linkages influence innovation at different stages of the innovation process is important . Of perhaps equal importance, however, is the role of internal 'openness' and connectivity in innovation. For example, it has been argued that team working may facilitate knowledge integration and information exchange (Grabher 2001, 2002, 2004; Whitley 2006) and the development of trust and mutual learning (Creed and Miles, 1996). Positive empirical evidence also exists suggesting the benefits of cross-functional teams on firms' innovation outputs (Tidd and Bodley 2002). Cooper and Kleinschmidt (1995), for example, identify firms' use of cross-functional teams as one of the key success factors in new product development projects, while Gupta and Wilemon (1996) emphasise the importance attached to the development of cross-functional teams by R\&D and technology managers. And Nakata and Im (2010) find that bringing together the skills, efforts, and knowledge of differing functions in a new product development team leads to the generation of high-performing new products. However, these studies predominantly consider team working and cross-functional teams in the context of manufacturing.

Our central focus in this paper is the process through which business service firms gather information or create knowledge, translate that knowledge into specific market offerings, and then seek to use these new innovations to generate growth ${ }^{1}$. This approach segments innovation into key stages and each stage involves relationships with external agents - other service providers, manufacturing firms and consumers - and

\footnotetext{
${ }^{1}$ Other firms may then benefit of course as knowledge or productivity spillovers may also then lead to improvements in the performance of other co-related or co-located firms (Klette, Moen, and Griliches 2000; Beugelsdijck and Cornet 2001).
} 
with internal actors through internal team working and cross-functional working. Crucially - and we believe uniquely - we are able to consider internal and external aspects of openness at different stages of the innovation process, and so explore how different external links are important at different stages of innovation, and how aspects of team working vary in importance at different stages of the innovation process. In order to explore these issues we make use of the concept of the innovation value chain (Hansen and Birkinshaw 2007; Roper et al 2008), which conceptualises the innovation process as comprising three interlinked stages of knowledge generation and sourcing, through transforming this knowledge into new services, and finally the commercialisation of these new services leading to business growth.

Our study makes three main contributions to the existing literature. First, our analysis integrates the activity-based concept of the innovation value chain (IVC) - the separation of the innovation process into three stages - with the growing literature on the benefits of 'openness' in innovation strategy. This involves balancing concerns about the internal organisation of firms' innovation with evidence on firms' external relationships in each stage of the IVC. In particular, we are able to distinguish firms' external relationships by their functional content and therefore relate these relationships to the different stages of the innovation process. In this sense our data go beyond existing surveys such as the Community Innovation Survey (CIS) which contains questions on the involvement of external partners, but no information on the stage of the innovation process at which they are involved. This provides an unusually rich empirical picture of the impact of openness in knowledge-based services and its implications for innovation success and business growth. As far as we are aware no previous analysis has considered this. Secondly, we introduce the concept of encoding linkages. These are linkages with external actors which take place between the more exploratory (knowledge sourcing) and exploitative stages of the innovation process, and which have previously been little considered in the innovation literature. As we show below, this represents not only a conceptual contribution, but also an empirical one: encoding linkages are qualitatively different in nature from the more commonly considered exploratory and exploitative relationships. Third, we are able to shed light on the roles of R\&D and design in business services, and show that design plays a part in permitting firms to absorb external ideas similar to the absorptive capacity role often attributed to $R \& D$ in manufacturing. 
The remainder of the paper is organised as follows. Section 2 discusses innovation in business services. Section 3 describes our model of the innovation process and introduces the concept of encoding linkages. Section 4 describes the dataset and estimation techniques used in the empirical analysis. Empirical results are discussed in Section 5, and Section 6 summarises and discusses the results.

\section{Innovation in Business Services}

Services have become the main source of employment in developed market economies. This shift towards service work has altered the ways in which economists conceptualise services. Adam Smith discounted services as essentially unproductive labour involved in the creation of intangibles incapable of producing value in the same way as manufacturing (Smith 1776 (1977): 430; Bryson and Daniels 2010: 86-87). Services are now considered to create value in their own right and also to play an important role in adding value to goods (Vandermerwe 1993; Bryson 2010). The term 'service' describes a heterogeneous collection of activities that includes business and professional services, finance and consumer services. Further complexity comes from the existence of three types of service innovation: the development of new or significantly improved services; the development of new or significantly improved methods of service production or process innovation and alterations in organisational structure or organisational innovation (Hipp et al., 2000).

There is a developing theoretical literature in to the relationship between services and innovation (Gallouj 2002; Gallouj and Savona 2010) that can be classified into four basic types. First, the service innovation literature was initially informed by the analysis of innovation in manufacturing based on new product development (NPD) (Menor et al. 2002). Second, it was argued, three fundamental differences between manufacturing and service innovation invalidated the NPD models application to services (Callon et al. 1997): service innovation requires simultaneous innovation in products and processes; there is no separation between product innovation and organisational innovation in services; and there is no distinction between the creation of a service offer and the activity of production and/or commercialization. New service development (NSD) models were formulated on the understanding that successful service innovation 
required the application of a formal NSD process with clearly identifiable stages ${ }^{2}$ (Cooper and Edgett 1996; Stevens and Dimitriadis 2005). Much of this literature was based on service innovation that is largely driven by technological innovation rather than various forms of soft innovation (Stoneman 2010).

Third, there are studies that focus on the innovation process, but take into consideration that this is a complex process based on technological and non-technological drivers. This perspective is valuable as it highlights the importance of technological innovation, but also soft innovation (Howells 2000; Daniels and Bryson 2002). Fourth, the NSD approach has led to a call for the development of a science of service engineering that would explore methods designed to enhance the effectiveness of service innovation (IfM and IBM 2008; Spohrer \& Maglio 2008; Maglio, et al. 2010).

There are problems with the fundamental differences identified by Callon et al (1997) as they are not applicable to all types of services and perhaps most appropriate for capital intensive services rather than the supply of business services. For business service firms, new products are initially developed by a process of co-production with their clients and external partners but to be further exploited these innovations must also be commercialised. This process of co-production involves complex iterative interactions with collaborating suppliers and consumers and takes many forms. It may involve the acquisition of external ideas that are then transformed internally into a product that can be sold to other companies. A client's problem may be so complex or unusual that a business service firm has to develop a solution based on the acquisition of new knowledge. This represents a process of crafting a solution based on a client's problems by bringing together a multi-functional team that combines multiple individual experiences, knowledge and competencies. These types of bespoke solution must be exploited by a business service firm through a process of commercialization that involves spreading the knowledge throughout the firm and also by creating new standardised services.

There is a danger in assuming that all solutions provided by business service firms are bespoke services. Business service firms provide customised co-produced solutions to

\footnotetext{
${ }^{2}$ This forms an obvious link to the innovation value chain approach outlined below.
} 
their clients (Greenwood et al. 2005; von Nordenflycht 2010), but many of these solutions are 'partially customised' rather than 'bespoke' solutions (Hipp et al. 2000: 427). This is to distinguish between standardised or customised solutions (Sundbo 2002) but this is not a simple bi-polar distinction. A business service firm can provide wholly standardised services, largely standardised services, bespoke services and partially customised services (Hipp et al. 2000: 427). These are not mutually exclusive categories as a largely standardised service can be partially customised through a process of coproduction. The construction of a bespoke or partially customised solution provides an opportunity for the development of a new wholly or largely standardised product. The crafting of a bespoke solution is based on encoding linkages that may produce a product that can be exploited though its transformation in to a generic product that can be subsequently crafted to meet each client's requirements. Exploring the relationship between customer and business service supplier is essential for understanding the coproduction of new service innovations but also the process by which existing services are transformed into customised solutions via a process of co-production. These represent different types of co-production relationship with the former based around encoding linkages. In a review of the literature on innovation theory and services Gallouj and Savona (2010: 43) identify that one of the remaining conceptual and empirical gaps involves understanding the role customers play in service innovation and we argue that encoding linkages plays an important role in this process.

\section{Exploratory, encoding and exploitative linkages: the innovation value chain}

Our focus here is the process through which firms source knowledge, innovate and then exploit or commercialise innovation to generate business growth. We regard the innovation process as 'open', emphasising the potential importance of firms' internal and external connections and the pool of potential partners to whom they might relate at each stage of the process.

Hansen and Birkinshaw (2007) suggest that this end-to-end process from knowledge investments to growth can be represented as an innovation value chain (IVC) comprising three stages. The first of these includes firms' efforts to source the bundle of different types of knowledge necessary for innovation (Hansen and Birkinshaw 2007; Roper et al 2008). This may involve firms undertaking in-house knowledge creation - 
through either design or R\&D activities - alongside, and either complementing or substituting for, external knowledge sourcing (Pittaway et al. 2004). The next stage in the innovation value chain is the process of transforming this knowledge into new services or business processes. This 'encoding' activity may again involve a combination of firms' internal and external resources, and we model this using the standard innovation production function approach, extended to allow for external linkages (Geroski 1990; Love and Roper 1999). The final stage in the IVC relates to the exploitation of firms' innovations through product creation and the generation of added value through commercialisation. This we model using a business growth equation akin to those widely used in the small business literature (Barkham et al. 1996; Mole et al. 2008). Here again we allow the profile of firms' external interactions - particularly with customers - to influence the innovation-growth relationship.

The activity based structure of the IVC and the separation of knowledge sourcing, transformation and exploitation activities has implications for the type and function of external linkages at each stage of the IVC. Originating with the work of March (1991) and Levinthal and March (1993), consideration has been given to the difference between 'exploratory' and 'exploitative' learning which may take place through firms' external relationships. Here, however, we are concerned with the type and function of firms' external linkages at all three stages of the innovation value chain-sourcing knowledge, transforming knowledge, and exploiting knowledge.

Exploration can be defined as 'the pursuit of knowledge, of things that might come to be known,' and exploitation as 'the use and development of things already known' (Levinthal and March 1993, p105). In terms of new product development, exploration therefore involves seeking new revenue-generating opportunities through potential new products and processes, and exploratory linkages align well with the first stage of the IVC in which firms seek new knowledge which can provide the basis for innovation. Such relationships may be serendipitous and ad-hoc, and involve risk-taking and uncertainty, as profitable outcomes cannot be guaranteed. For services it can also involve the development of innovations that are initially based on customised services created via a process of co-production or co-development, but such innovations must ultimately be identified and transformed into commercial products (Edvardsson et al., 2006). Relationships focussed on exploitative learning, with their focus on adding value, 
align well with the third - exploitation - stage of the IVC, in which new products and processes are commercialised in the marketplace. Such relationships are likely to be highly focussed and based firmly around commercialising the products and processes developed earlier. Thus, as Rothaermel and Deeds (2004) point out, the explorationexploitation model implies a clear sequence of use: exploitation cannot take place without prior exploration.

However, this dichotomy may be insufficient in the context of the new service development process. For the middle stage of the IVC, knowledge transformation, we require a third form of relationship which we call 'encoding' linkages and in which the focus of learning is around the effectiveness of the innovation process itself. This is the stage at which new ideas start to be turned into new products and processes: encoding is therefore more than just serendipitous knowledge creation that could come from, for example, random customer interactions, but involves strategic engagement with customers, suppliers and other external partners which lead directly to new products and processes being developed, but before they are fully commercialised. The functional content of these relationships is no longer exploratory and serendipitous, as in exploratory relationships, but based on a process of encoding as firms seek to develop their innovation capabilities and routines, and build new capabilities with the goal of developing new products and processes which can subsequently be exploited to create value (Cohen and Levinthal, 1990). Encoding transforms service innovation into a process that has the potential to create new products, and encoding linkages represent part of this key innovation process ${ }^{3}$. For example, inter-organisational learning may be contributing to the development of firms' innovation management competencies (Dunphy et al 1997) by improving their project management techniques (Omar and Mohan 2006), skills in customer engagement, collaboration, and flexibility (Agarwal and Selen 2009), or innovation speed (Knockaert et al. 2009). Relationships and capacity creation of this kind are therefore neither exploratory nor are they solely related to the commercialisation of previously developed knowledge; rather they are the process of encoding knowledge into innovative capabilities and ultimately viable new services

\footnotetext{
${ }^{3}$ Sundbo (2010: 282) argues there is a danger that the service innovation process stops as the organisation and the management 'forget' that there was an innovation, as it is rare for a manager or a department to be assigned responsibility for managing the process. Encoding, and the linkages which form part of the process, help address this possible weakness in service innovation.
} 
and processes in anticipation of market exploitation, and so are not fully captured in the simple exploration-exploitation dichotomy.

Our conceptualisation of the innovation value chain is shown in Figure 1, showing the positioning of exploratory, encoding and exploitative linkages respectively. Uniquely, our dataset allows separate consideration of each of these forms of linkage, showing how different forms of external linkage can affect different aspects of the process of innovation.

(Figure 1 here)

\section{Operationalising the innovation value chain}

In this sub-section we describe how the innovation value chain approach can be operationalised to explore the effects of exploratory, encoding and exploitative linkages described above. In the first stage we identify relates to firms' attempts to gather the knowledge which provides the starting point for innovation activity (Figure 1). This knowledge could be technological, related to market structure or opportunities or ideas about new business models. Any of these might provide the starting point for new innovation and might arise either from firms' own internal knowledge generation activities - e.g. design or R\&D - or their linkages to external partners. In this stage of the innovation process we are therefore concerned with the importance of externally sourced ideas in the innovation process and the extent to which this is influenced by firms' internal capabilities and exploratory linkages (Figure 1). Different types of knowledge might also be accessible through different types of external relationships: product knowledge or information about new market opportunities is perhaps most likely to stem from forward linkages to customers (Joshi and Sharma 2004; Love and Mansury 2007); while information on new technological developments are perhaps more likely to emerge from backward links to either suppliers or external consultants (Horn 2005; Smith and Tranfield 2005) or linkages to universities or other public research centres (Del Barrio-Castro and Garcia-Quevedo 2005) and professional bodies; ideas about new business models may emerge from linkages to either competitors or through joint ventures (Hemphill 2003; Link, Paton, and Siegel 2005). 
This suggests that the proportion of new service ideas which come from outside the firm $\left(\mathrm{XI}_{\mathrm{i}}\right)$ can be represented as:

$$
X I_{i}=\beta_{0}+\beta_{1} F C A_{i}+\beta_{2} D E S_{i}+\beta_{3} R D_{i}+\beta_{4} K A A_{i}+\varepsilon_{i}
$$

Where $\mathrm{FCA}_{\mathrm{i}}$ is a vector of firm characteristics intended to reflect the internal availability of knowledge resources for innovation. In addition to measures such as size, age, and labour skills, we include here an indication of the extent to which the firm uses multifunctional teams as part of its knowledge sourcing activities. We anticipate a positive relationship between the variables in $\mathrm{FCA}_{\mathrm{i}}$ and $\mathrm{XI}_{\mathrm{i}}$, reflecting complementarity between firms' internal knowledge resources and their external linkages (Agarwal and Selen 2009). A measure of public support received by the firm for innovation is also included in $\mathrm{FCA}_{\mathrm{i}}$, which we anticipate will have a positive catalytic effect on firms' innovation activity and therefore knowledge seeking (Buiseret, Cameron, and Georgiou 1995; Falk 2004; Luukkonen 2000; OECD 2006). KAA $\mathrm{KA}_{\mathrm{i}}$ is a vector of indicators summarising firms' exploratory relationships and we anticipate positive coefficients here reflecting the idea that the stronger is firms' external connectivity at the exploratory phase the greater the proportion of new ideas are likely to be generated externally. $\mathrm{DES}_{\mathrm{i}}$ is internal spending on design while $\mathrm{RD}_{\mathrm{i}}$ is internal spending on $\mathrm{R} \& \mathrm{D}$. Signs on these two variables are ambiguous in equation (1). While we would anticipate that both types of investment are positively related to innovation it is less clear a priori how they would be related to the percentage of firms' new ideas generated externally. If internal knowledge investments are a substitute for external knowledge sources then we would anticipate negative coefficients; if internal and external knowledge are complementary we might anticipate a positive sign (Love and Roper 1999; Cassiman and Veugelers 2002; Schmidt 2010).

The second stage in the innovation value chain is the transformation of knowledge inputs to form codified innovation outputs. This process is typically modelled using an innovation or knowledge production function which relates innovation outputs to knowledge inputs (Griliches 1992; Love and Roper 1999). The effectiveness of firms' knowledge transformation activities may then be influenced by the firms' own internal resources as well as their ability to draw on external resources through encoding 
linkages to other organisations. In terms of innovation outputs, we here follow the suggestion of Pittaway et al. (2004) who emphasise the importance of examining different dimensions of innovation activity, anticipating that knowledge inputs may have differential effects on each type of innovation outputs. Joshi and Sharma (2004), for example, suggest the importance of knowledge of customers' preferences in shaping the commercial success of firms' innovation and Edvardsson et al (2010) have highlighted the importance of integrating customers in to the service innovation process, while Roper et al. (2008) emphasise the greater value of supplier linkages for process change. Here we focus on two indicators of innovation outputs: the percentage of sales derived from innovative services and an indicator of the diversity of firms' innovation activity.

In general terms we write the innovation production function as:

$$
I O_{i}=\delta_{0}+\delta_{1} F C B_{i}+\delta_{2} D E S_{i}+\delta_{3} R D_{i}+\delta_{4} X I_{i}+\delta_{5} K A B_{i}+\varepsilon_{i}
$$

Where $\mathrm{IO}_{\mathrm{i}}$ is an innovation output indicator and $\mathrm{FCB}_{\mathrm{i}}$ is a vector of firm characteristics which might influence the effectiveness of firms' knowledge transformation activity. Where firms' internal knowledge resources are strong we would expect this to contribute positively to the efficiency with which firms develop new innovations (Crépon et al. 1998; Lööf and Heshmati 2001, 2002). Similarly we expect firms' innovation outputs to be positively related to public support for firms' innovation activity an indicator of which is also included in $\mathrm{FCB}_{\mathrm{i}}$ (Link et al 2005). Firms' in-house investments in design $\left(\mathrm{DES}_{\mathrm{i}}\right)$ and research and development $\left(\mathrm{RD}_{\mathrm{i}}\right)$ may also be important here, reflecting not only their direct positive impact on innovation capability (Marsili and Salter 2006), but also their impact on firms' ability to absorb and effectively utilise external knowledge as part of their innovation activity (Griffith et al 2003). We therefore anticipate positive coefficients on both variables in equation (2). Also included in the innovation production function is $\mathrm{KAB}_{\mathrm{i}}$ a vector representing firms' encoding linkages. As before we consider the potential benefits to the firm of working with a range of types of partner. The functional content of these relationships is no longer exploratory, however, but encoding as firms seek to develop their innovation capabilities and routines. We expect such encoding relationships with external partners to have a positive impact on innovation outputs. 
The causal connection between the initial and the second stage of the IVC is made by the inclusion in equation (2) of the dependent variable from equation (1) - the proportion of new service ideas derived from outside the firm. If, as the open innovation literature suggests, openness to external ideas is beneficial for innovation (Chesbrough 2006; Chesbrough 2003), the coefficient on this variable will be positive.

The third and final stage in the innovation value chain is the exploitation of innovation (Figure 1). At this point we envisage that firms' knowledge, sourced in stage 1 of the IVC, has been codified into specific service or business process innovations. It is these new market offerings or business models that might drive enhanced business growth, and which provide the link between firms' knowledge sourcing activities and corporate performance. The strength of this linkage, however, will depend on firms' ability to effectively exploit their new service innovations.

As before we argue that the effectiveness of firms' knowledge exploitation activities may depend on both the strength of firms' internal resource base as well as their (exploitative) partnerships with other organisations. This relationship can be summarised as follows:

$$
B O_{i}=\chi_{0}+\chi_{1} I O_{i}+\delta_{2} F C C_{i}+\delta_{5} K A C_{i}+\varepsilon_{i}
$$

Where $\mathrm{BO}_{\mathrm{i}}$ is a business output measure (e.g. growth), $\mathrm{IO}_{\mathrm{i}}$ are indicators of innovation outputs, $\mathrm{FCC}_{\mathrm{i}}$ is a vector of indicators of firms' internal resource base and $\mathrm{KAC}_{\mathrm{i}}$ is vector of exploitative partnerships. Here coefficients on $\mathrm{IO}_{\mathrm{i}}$ are of particular interest as these form the causal link between the second and third stages of the IVC. The anticipated positive coefficients here would suggest that innovation outputs have a positive impact on business growth.

Together equations (1), (2) and (3) reflect the innovation process from firms' investments in knowledge sourcing or creation through innovation to business growth. Although their functional content differs throughout the process, firms' internal resources, the internal organisation of the innovation process and their external relationships - exploratory, encoding and exploitative - all play a potentially important role in ensuring the effective translation of knowledge into business value. 


\section{Data and Methods}

Our econometric analysis is based on a new firm-level survey designed specifically to provide a representative view of the innovation process in UK business services (Roper et al., 2009). The target population for the survey included all firms with more than five employees, and in each of the six sectors covered a structured sample was constructed distinguishing between three business size-bands (5-19 employees, 20-99 employees; and 100 plus employees $)^{4}$. A random sample of firms was drawn within each sector and sizeband from data provided by a commercial database provider. Telephone interviews were then conducted with the managing director, a member of the senior management team or the individual with lead responsibility for new product or service development within each firm. Interviews were conducted using Computer Aided Telephone Interviewing (CATI) which has the advantages of allowing real time verification of numerical responses and the rotation of item lists. One disadvantage of this approach, however, was that a significant proportion of respondents were unable or unwilling to provide financial information relating to the turnover or growth of the firm. This reduces the number of observations which can be included in the 'estimation sample' where estimation involves these financial variables.

Questionnaire design was informed by exploratory face-to-face interviews with firms and representative groups in each sector ${ }^{5}$. These interviews were used to identify key aspects of innovation in each sector and to develop item lists and appropriate language. The face-to-face interviews were critical for the design of the telephone survey. During these interviews the types of innovation occurring in each sector were identified and the innovation process explored. It is worth considering two issues that played an important role in the design of the telephone survey. First, the definition of 'new services' involved firms being requested to identify new product and process developments that were occurring in their sector and then to identify any product or process innovations that had been introduced by their firm over the last three years, For accountancy firms, for example, process innovations focused on making the accountancy process more cost effective to deliver better value for money. In some cases, this involved outsourcing

\footnotetext{
${ }^{4}$ Sectoral coverage was as follows (2003 SIC codes): Accountancy services (SIC 74.12), Architectural services (SIC 74.2), Consultancy services (SIC 74.14), Legal services (SIC 74.11), Software and IT services (SIC 72.2, 72.3, 72.4), Specialist design (SIC 74.87/2)

${ }^{5}$ Two exploratory interviews with firms and one exploratory interview with a representative group was undertaken in each sector during April/May 2009.
} 
work associated with tax returns to India, introducing electronic data handling systems or new software to speed up internal processes. New service innovations included offering financial management 'health checks' to existing clients, or environmental or corporate social responsibility audits. Second, innovation in business services is a collective process based on an interplay between internal and external producers and carriers of knowledge (Bessant and Rush, 1995, Anand et al., 2007). This process of coproduction requires external ideas obtained from many sources including clients, suppliers, competitors and consultants. These sources were identified for each sector during the face-to-face interviews. It is important to identify the sources of external ideas, but essential to explore the ways in which a business service firm transforms the acquired expertise into a product that may be commercialised. This is to distinguish between the collective process of co-production, or encoding linkages, and a firm's internal processes that transform external ideas into potential products. The IVC approach is especially useful in this respect as it identifies these as distinct, but related processes.

A pilot telephone survey was conducted in June 2009, and the main telephone survey was conducted between June and August 2009. In all, 1151 valid responses were obtained in the 'whole sample', a 15 per cent response rate, consistent with other telephone surveys of this type ${ }^{6}$. Of these 651 firms ( 57 per cent) - the 'estimation sample' - provided complete financial information enabling them to be used in all of our estimation. Descriptive statistics for the whole sample (i.e. 1151 firms) and the estimation sample (i.e. 651 firms) are given in Table 1 to allow the characteristics of the whole and estimation samples to be compared ${ }^{7}$. In general terms we observe little difference between the summary characteristics of the whole sample and estimation sample suggesting the latter is broadly representative (Table 1).

(Table 1 here)

\footnotetext{
${ }^{6}$ Survey response was as follows: Accountancy services, 192; Architectural services, 217: Consultancy services, 190; Legal services, 178; Software and IT services, 189; Specialist design, 189 (Roper et al, 2009, Table 2 p. 19).

${ }^{7}$ In Table 1 and in the econometric analysis survey responses are weighted to give representative results and correct for variable response between firm size groups. See Roper et al., (2009), Annex 1 for details of survey response and the derivation of weights.
} 
Respondents are generally mature firms (on average 27 years old), operating on a single site and, reflecting the knowledge-intensive nature of the sectors covered, have a workforce of which around half are graduates (Table 1). Only around 5 per cent of firms surveyed are externally-owned, although around 44 per cent reported export sales. Around 45-51 per cent of firms indicated that they had introduced at least one new service in the previous three years, with an average of 14- 17 per cent of sales being derived from such new services ${ }^{8}$.

An average of around 11-13 per cent of new service ideas arose outside the firm although this measure exhibited considerable sectoral heterogeneity. Consultancy firms were most open to external ideas (13.4 per cent), and accounting and legal firms least so (4.5 per cent and 4.9 per cent respectively). Patterns of external linkages at each stage of the IVC are summarised in Figure 2. In general terms, exploratory links are most common, and there is a reduction in the extent of firms' external linkages in subsequent stages of the IVC. More specifically, in the first - knowledge sourcing - stage of the IVC the most common links are to customers (37-43 per cent), suppliers (23-28 per cent), competitors (29-33 per cent) and trade associations (25-27 per cent). In the second stage of the IVC external (encoding) relationships are generally less common with the most frequent link again to customers (20-24 per cent). In terms of commercialisation of innovation around one in ten firms reported working with suppliers and trade associations with many also employing a range of different forms of customer interaction (Joshi and Sharma 2004; Love and Mansury 2007). More specifically, firms were asked whether they engaged with their customers in five specific ways (involve customers in service evaluation and development; monitor customer feedback to shape new product and services; use structured CRM systems or approaches; hold regular customer seminars or workshops on new services; develop customer-specific solutions). Responses were then used to calculate a Customer Interaction Index, and on average each firm was using 51-52 per cent of these contact mechanisms (see Annex 1).

(Figure 2 here)

\footnotetext{
${ }^{8}$ Innovation was defined as the introduction of any new or significantly improved services. The definition therefore relates to services which are new to the firm, not necessarily to the market.
} 
R\&D intensity and design intensity - expenditure as a percentage of sales - were also captured where possible within the survey, although only around 57 per cent of respondents - the estimation sample - provided this information ${ }^{9}$. More firms were able to give an indication of the importance of team working, customer interaction and IP protection measures used in their innovation activity. In each case, these variables are constructed as indices reflecting firms' responses to item checklists relating to each type of activity. In the case of team working, for example, which is included in the second stage of the IVC, we identified five different aspects of team working (see Annex 1). Where a respondent agreed with all of these statements they scored 100 per cent on the index with this declining proportionately. Essentially similar indices are used to reflect firms' customer interaction and IP protection strategies in the third stage of the IVC and multi-functional working in each stage of the IVC (See Annex 1).

For the first and second stages of the IVC - relating to knowledge sourcing and transformation - our dependent variables are defined as percentages: in the first stage of the IVC the percentage of new service ideas from outside the firm; and in the second stage the percentage of sales derived from innovative services and the diversity of innovation. These variables have both upper and lower bounds suggesting the applicability of the Tobit model. Potential issues arise at the second stage of the innovation value chain, however, relating to the potential endogeneity of the percentage of externally sourced ideas with respect to the measures of innovation which form the dependent variables in equation (2). We test for the potential endogeneity of the percentage of externally sourced ideas using a Hausman test based on set of strong instruments derived from the first stage of the IVC (Cameron and Trivedi, 2007) ${ }^{10}$. At this stage of the IVC, the Hausman tests do suggest endogeneity and so we report instrumental variables Tobit estimates of the innovation production functions with Amemiya-Lee-Newey minimum chi-sq statistics for over-identification. We adopt a similar approach to the potential endogeneity of the innovation output measures

\footnotetext{
${ }^{9}$ Design involves the design of service experiences, service spaces, web-based consumer interfaces and anything involving interactions with customers. In our survey firms were asked to identify how much they 'spent on the design of new or improved products or services over the last year? Please include expenditure on salaries, wages and staff time as well as equipment and any 'bought in' services'. And for R\&D, 'how much have you spent on R\&D over the last year? Please include expenditure on salaries, wages and staff time as well as equipment and any 'bought in' R\&D services'.

${ }^{10}$ We test the strength of the set of instrumental variables separately, see below.
} 
(percentage of innovative sales, diversity of innovation) with sales growth. This issue has been discussed extensively in the literature, and a range of potential approaches have been adopted including two-stage estimation methods (Crépon et al. 1998) and the simultaneous estimation of the innovation and augmented production functions (e.g. Lööf and Heshmati, 2002). In our data, however, Hausman tests for the endogeneity of each of the innovation variables in the sales growth models all prove insignificant. We therefore estimate log sales growth using OLS.

\section{Results}

Table 2 reports our models of firms' knowledge sourcing activities with the dependent variable being the share of new service ideas coming from outside the firm (equation (1)). As with all estimations, sectoral dummy variables are included but not shown for reasons of space. Perhaps the most notable feature of these models is the relative lack of significant coefficients; none of the indicators relating to firms' internal resource base, and only one of the variables reflecting firms' exploratory knowledge linkages has a significant effect on the share of new service ideas coming from outside the firm.

There are nevertheless some strong and consistent results although the overall fit of the models is relatively weak with Pseudo- $\mathrm{R}^{2}$, s around 6 per cent. First, having a multifunctional internal team involved in this exploratory stage of the innovation process has a highly significant and positive effect. This may reflect the capabilities of teams to facilitate knowledge integration and information exchange (Grabher 2001), develop trust and mutual learning (Creed and Miles 1996), and overcome hierarchical and spatial barriers to communication (Zeller 2002) ${ }^{11}$. Secondly, firms' investments in design are linked positively to the share of new service ideas coming from outside the firm, while the effects of in-house R\&D capability are statistically insignificant. ${ }^{12}$. The importance of design investments (intensity), and more particularly the presence of inhouse design capability (Models 3 and 4, Table 2), emphasises the argument made by

\footnotetext{
${ }^{11}$ In fact our results provide a fairly ready interpretation in terms of the impact of multifunctional working on the proportion of externally sourced service ideas. Say for one sector our index of multi-functionality is based on five occupational groups, i.e. it takes value 20 if one skill group is involved in knowledge sourcing, 40 if two skill groups are involved etc. Then the marginal effects .22-.32 suggest that adding an additional skill group to the knowledge sourcing team would on average increase the proportion of externally sourced ideas by 4.4-6.4 per cent.

${ }^{12}$ Note that this does not mean that R\&D necessarily has no role to play in innovation, which is the domain of the second set of estimations.
} 
Candi and Saemundsson (2008) that design plays a consistently important part in services innovation across a range of different contexts ${ }^{13}$. Indeed, our results suggest that for services firms design capability may be a more important contributor to absorptive capacity than in-house R\&D. Thirdly, our results emphasis the importance of service firms' exploratory links with customers. For our sample, firms with exploratory links to customer have on average around 30 percentage points more external ideas for new services than equivalent firms without such exploratory links.

(Table 2 here)

Overall, our results suggest that scale factors such as the size, ownership, and skill-base of services firms play little role in shaping their exploratory capabilities to identify new service ideas outside the firm. For professional firms the skill sets are determined by the professional bodies; innovation may be limited by constraints placed on professional workers by their professional bodies (Bryson and Daniels, 2008). Instead, the dominant influence is the organisation or perhaps utilisation of firms' internal resources, reflected in its use of multifunctional teams and the presence of an in-house design function, allied with exploratory links to customers. Other types of exploratory links (to competitors, consultants, universities) also had positive effects on the external proportion of firms new service ideas although these factors were statistically insignificant.

The next stage of our estimation is the innovation production function equation (2), and reflects firms' ability to translate knowledge - both internal and externally sourced into innovation and new marketable products and services. In these models we therefore include the proportion of externally sourced service ideas as an explanatory variable anticipating a positive coefficient. Two different dependent variables are employed in this estimation; the first is the percentage of sales from innovative products as defined earlier (Table 3 models 1 and 2), and the second is a measure of the diversity of firms'

\footnotetext{
${ }^{13}$ To explore this issue in more detail we partitioned the design variables between the design-based sectors in our sample (specialist design and architectural services) and the other sectors and tested the equality of the coefficients. In both Model $1(F(1,558)=0.90, \rho=0.34)$ and Model $3(F(1,910)<0.00$, $\rho=0.96$ ) of Table 2 coefficients were similar between the design and non-design based sectors. An essentially similar result is evident in the innovation production function (Model 1, Table 3), 1 $(\mathrm{F}(1,541)=1.48, \rho=0.22)$.
} 
innovation activities (Table 3 models 3 and 4$)^{14}$. In each case the percentage nature of the dependent variable, bounded at zero and one hundred, suggests the Tobit estimator. In each case too there is the possibility that the percentage of externally sourced ideas the link to the first stage of the IVC - is endogenous, potentially requiring the use of an instrumental variables (IV) approach. Given the reduction in efficiency usually involved in IV estimators, however, this approach is only desirable if there is clear evidence of endogeneity and we therefore conduct a Hausman test to evaluate the endogeneity of the percentage of service ideas from outside the firm (Cameron and Trivedi, 2007, p. 275).

This involves developing a set of instruments for this variable which, following the sequential logic of the IVC, we derive as a subset of the variables used in the models in Table 2. More specifically, we use a set of three instrumental variables which specifically reflect firms' knowledge sourcing activities - government support for knowledge sourcing, knowledge sourcing links to customers, and multi-functionality in knowledge sourcing. A reduced-form regression of these variables on the percentage of service ideas from outside the firm suggests these are strong instruments, with the equation $\mathrm{F}(3,1039)=69.90$, well above the conventional threshold $(\mathrm{F} \geq .10)$. The selected instruments are therefore conceptually justified through the innovation value chain - they are linked to the development of external ideas in the first stage of the innovation process, but have no conceptual link to the development of innovations in the second stage - and are econometrically valid. For the Hausman test we then included predicted values from this reduced form model as a regressor in conventional Tobit models of the percentage of innovative sales and the diversity of innovation. In both cases the predicted values were statistically significant $(\mathrm{t}=1.80$ and $\mathrm{t}=4.62$ respectively) suggesting the endogeneity of the percentage of service ideas from outside the firm and the need for an IV approach. In Table 3 we therefore report IV Tobit models of the percentage of innovative sales and the diversity of innovation, and in each case report the Amemiya-Lee-Newey minimum chi-square test for over-identification (Amemiya,

\footnotetext{
${ }^{14}$ This variable is an index of firms' involvement in six different types of innovative activity. These are; product innovation; business process innovation; strategic innovation (i.e. the implementation of a new or significantly changed corporate strategy); organisational innovation (i.e. implementation of a major changes to organisational structure such as introduction of cross-functional teams, outsourcing of major business functions); marketing innovation (i.e. the implementation of changes in marketing concepts or strategies); and innovation in advanced management techniques, including the new implementation of systems such as knowledge management or Investors in People.
} 
1978; Newey, 1987; Lee, 1992) ${ }^{15}$. Test values do not provide evidence against the overidentification in the models suggesting the validity of the chosen instruments.

In both sets of models, we find a broad range of resource and market indicators prove significant along with some types of encoding linkages. We also find that openness reflected in the proportion of externally sourced new product ideas has a strong and significant effect on the diversity of innovation, and a positive but insignificant effect on the percentage of innovative sales. The results for the diversity of innovation (Table 3 , Models 3 and 4) emphasise the strength of the causal link between firms' openness to new ideas and their innovation outputs and, more broadly, the value of openness in the exploratory stage of the innovation process.

(Table 3 here)

Considering first the results for the percentage of innovative sales we again find that general indicators of firms' internal resources and scale - size, age, ownership, group membership - prove largely insignificant. More surprising perhaps, given the positive results of other studies, is that we find no significant relationship between either exporting and innovation (Gourlay et al 2005; Roper and Love 2001; Wakelin 1998) or between workforce skills and innovation (Freel 2005; Leiponen 2005). The insignificance of the R\&D variables may reflect the frequent argument that services innovation is less technologically-based than that in manufacturing (although see Gourlay et al, 2005; Blind and Jungmittag, 2004).

Instead, we find more positive relationships between the percentage of innovative sales and a group of indicators specifically related to the internal organisation of firms' innovation activity. As anticipated, team working has a strong positive effect as does multi-functionality (Table 3, Models 1 and 2$)^{16}$. Both suggest the importance of internal knowledge sharing in achieving successful innovation and provide support for other studies which have stressed the importance of firms' utilisation of human resources for

\footnotetext{
${ }^{15}$ These models are estimated using the IVTobit estimator within STATA. The Amemiya-Lee-Newey test is estimated using the Overid prodedure (Baum et al., 2006).

${ }^{16}$ The team working index relates to the second stage of the IVC only. It reflects the extent of the firm's commitment to team working using responses to four qualitative variables such as 'our firm invests in training for team- working for team working'. Thus a higher value of the index reflects a greater commitment to team working in the firm.
} 
innovation (Michie and Sheehan 2003). Two external factors also have a significant impact on the percentage of innovative sales: public support and the number of competitors. Firms' receiving government support for innovation had on average 12-16 percent more innovative sales than those not receiving such support. This suggests the additionality of public support for innovation, reflecting the findings of a range of other studies (Buiseret, Cameron, and Georgiou 1995; Hewitt-Dundas and Roper 2009). Some care is necessary in the interpretation of this policy effect, however, given the potential for 'better' or more innovative firms to self-select, or be selected, to receive public innovation support. Firms' market position, reflected in the number of competitors they face, also has a significant effect on the percentage of innovative sales 'with each additional competitor reducing the percentage of innovative sales by around 1.2 per cent (Table 3, Models 1 and 2).

Encoding relationships in general we find play a relatively limited role in influencing the percentage of innovative sales. Encoding linkages to commercial laboratories, however, are important and firms with such linkages as part of their knowledge transformation activity have on average 22 per cent more innovative sales (Table 3 , Models 1 and 2). The contrast with the earlier stage of the IVC, where exploratory links to customers were important as part of firms' knowledge sourcing activity, is particularly striking.

Results for the innovation diversity estimation (Table 3, Models 3 and 4) are show both similarities with and differences to those for the percentage of innovative sales. The crucial difference is in the importance of externally sourced ideas, which have a very significant positive effect on innovation diversity. Neither design intensity nor R\&D intensity are important here. Scale seems to be more important in terms of the diversity of firms' innovative activity than in terms of the proportion of innovative sales, reflected both in a positive and significant coefficient on firm size and in the negative coefficients on whether or not the firm is a single site company (Table 3, Models 3 and 4). This suggests that there are benefits of scale and having access to group resources in encouraging a range of innovation activity. Again too we find the internal organisation of firms' human resources important with team working having positive and significant effects on the diversity of innovation. As with the percentage of innovative sales we also find that encoding relationships have little general effect on the diversity of innovation. 
A specific positive effect is evident, however, reflecting firms' links to public research organisations (although not universities).

Our results on the percentage of innovative sales and the diversity of innovation suggest the factors which shape the effectiveness of firms' knowledge transformation activity. Three key effects are evident. First, for the diversity of innovation we find significant positive benefits from 'openness', i.e. having a larger proportion of externally sourced ideas. Such ideas clearly influence firms' abilities to to increase the breadth of their innovation activity to embrace new marketing, strategy and organisational innovations (diversity of innovation). Second, the internal organisation of firms' innovative activity - particularly the use of teams - has a positive and significant effect on innovation outputs. Third, encoding linkages are also important for innovation outputs with linkages to commercial laboratories important for innovative sales and links to public research agencies shaping the diversity of firms' innovation activity. In strategic terms our results suggest that maximising innovation outputs requires an openness to external ideas, effective internal organisation of resources and the development of appropriate encoding linkages. In summary, therefore, the optimal combination of 'openness' appears to be a high degree of openness to external ideas early in the process, coupled with a high degree of internal connectivity and team working at the second, encoding stage. In addition, the results of Table 3 broadly suggest that internal openness matters for innovation intensity, while external openness matters for diversity of innovation.

The final stage of the IVC is the exploitation of innovation the results of which we measure here using three-year business growth. Here again there is the potential for endogeneity of the innovation indicators in the sales growth models. As before we examine the endogeneity of each of the innovation indicators using a Hausman test (Cameron and Trivedi, 2007, p. 275). Following the same procedure as previously we first identified a set of instruments for each of the innovation measures derived from the previous (i.e. second) stage of the IVC. Here we use a set of eight instrumental variables: design intensity, public support for knowledge transformation, multifunctionality and team working in knowledge transformation and related links to suppliers, competitors and commercial laboratories. Reduced form regressions of an indicator variable for innovation, innovative sales and the diversity of innovation all have $F$ statistics well above the conventional level $(F(8,617)=76.62 ; F(8,610)=19.95$ 
and $F(7,619)=43.12$ respectively) suggesting the validity of each set of instruments. Including the predicted values from these estimations in sales growth models for the Hausman test then gave insignificant results (innovation, $\mathrm{t}=-0.17$, percentage of innovative sales, $\mathrm{t}=0.29$ and innovation diversity $\mathrm{t}=0.88$ ) suggesting the exogeneity of the innovation variables in each case.

In Table 4 we therefore report five simple OLS models linking growth to each of our innovation output measures: Model 1 includes a simple dummy variable reflecting whether or not firms introduced any new services over the 2006-09 period. Models 2 and 3 include the (log) percentage of innovative sales while Models 4 and 5 include the innovation diversity variable. Each of these variables proves strongly significant and positive in these models suggesting the importance of innovative sales and innovation diversity to business growth ${ }^{17}$. For example, being an innovator increases growth by an average of 22 per cent over the three-year period (Table 4, Model 1). These results are important in that they provide the causal link between the second and third stages of the IVC and the final connection between initial knowledge investments and business growth. Estimating similar models for sales per employee - a proxy measure for productivity - at the end of the sample period suggests rather different results, however, with no evidence of any significant innovation effects on sales per employee from either innovative sales or the diversity of innovation. This reflects other studies for manufacturing firms which have suggested similar results - i.e. that innovation influences business growth but not productivity, at least in the short-term (Roper et al., 2008).

(Table 4 here)

Other factors also prove important in shaping business growth. Reflecting other studies in the business growth literature, scale and vintage factors also prove important here with larger and older firms growing more slowly (Cressy 2006; Evans 1987; Hamilton et al 2002). Exploitative relationships, however, prove less important generally than we might have anticipated although, again, specific linkages to professional associations prove strongly significant. More specifically, firms which are part of professional associations grew 16-20 per cent more rapidly than those which were not. Again,

\footnotetext{
${ }^{17}$ As in the previous stages of the IVC the Pseudo- ${ }^{2}$, $s$ of the growth models in Table 4 are relatively low although similar to other models of business growth (e.g. Mole et al., 2008)
} 
however, some care is necessary in the interpretation of this result. Is this positive growth effect the result of membership itself or is it a selection effect with better firms attracted to join professional associations? Either way it is interesting that this 'association' effect is marginally smaller than the 'innovation' effect noted earlier (Table 4, Model 1).

\section{Discussion and conclusions}

Much of the recent literature on innovation has stressed the potential benefits of openness and receptiveness to external ideas as well as the potential value of external linkages as part of the innovation process. Here, using specially collected data for UK knowledge-based services firms, we are able to examine both issues in unusual detail. As far as we are aware, no previous study has been able to consider these issues in such depth for the entire innovation process from knowledge sourcing to firm growth.

Our empirical results can usefully be considered in four main themes relating to the role of external linkages in shaping firms' innovation and growth, the importance of organisational factors, the causal structure of the IVC, and finally other environmental factors which influence innovation outcomes.

First, our study offers new insights into the way in which linkages to alternative types of partner contribute to different stages of the innovation process. In particular, while previous studies based on the Community Innovation Survey (CIS) have emphasised the general importance of links to customers, we are able to show here that it is exploratory linkages to customers which are of primary importance in the first - knowledge gathering - stage of the IVC. This suggests that the most innovative firms have mechanisms in place to identify their most important customers and to develop collaborative relationships. Other linkages also prove important, particularly interesting being the importance of external commercial research organisations in the second (encoding) stage, and the very positive role played by professional associations in the third (exploitation) stage of the IVC. Using the IVC approach thus provides a more refined picture of these linkage effects, effects which are essentially conflated in the one-step innovation process underlying the CIS-type questionnaire design. 
Secondly, our results emphasise the importance of the internal organisation of the innovation process, particularly in the first two stages of the IVC. Here, multi-functional working and team working play positive and significant roles in boosting innovation outputs, effects exaggerated where a firm has an in-house design capability. Indeed, in our analysis these indicators of resource use prove more important than general indicators of resource quality such as graduate skill levels or R\&D intensity. Although this may reflect the nature of the sample of firms considered here - the majority of which have high levels of graduate employment - this does emphasise the importance of organisational design for innovation. In strategic terms these results suggest some clear priorities: multifunctional working and external exploratory links to customers can provide an important boost to the sourcing of external ideas; multifunctional working, teams and encoding links to commercial research organisations will then be important in translating these ideas into new marketable innovations; exploitative links to professional associations will then help firms maximise the growth benefits of their new innovations.

Thirdly, in terms of the causal links between elements of the IVC our analysis suggests that the links between the knowledge sourcing and knowledge transformation and between the knowledge transformation activity and exploitation are both positive and strongly significant (Tables 3 and 4). This provides evidence of the positive effects of openness to new ideas for innovation diversity as well as underlining the importance of innovation as a driver of business growth amongst knowledge-intensive firms. These results also suggest the validity of the causal process envisaged within the IVC framework. In strategic terms this emphasises the importance of innovation as a strategic priority for firms wishing to grow as well as emphasising the value of both service innovation and other types of marketing, strategic and organisational change. It also supports the potential value of the IVC approach as an analytical approach to evaluate the effectiveness of firms' innovation activities as suggested by Hansen and Birkinshaw (2007).

Finally, our analysis highlights two elements of the wider business environment which prove important in influencing firms' innovation outputs. Public support for knowledge transformation has a positive and significant resource augmenting effect on the percentage of innovative sales (Table 3 ) but we are able to find little positive influence 
of similar support either in the exploratory or exploitation stages of the IVC. The number of competitors also has a significant negative effect on the percentage of innovative sales, again an effect which seems limited to the second stage of the IVC. Both emphasise the importance of firms' operating environment for innovation as well as the potential role of government support in overcoming barriers to innovation.

Exploring these effects further using this or other similar datasets might provide additional clues as to routes through which the public sector might support innovation. We are conscious too that our analysis to date covers only business services and would be keen to see this extended to other sectors, particularly where innovation has a stronger technological component. In such industries some factors which prove rather insignificant here $-\mathrm{R} \& \mathrm{D}$, IP protection - might be expected to play more of a role. One other extension is planned - the matching of our cross-sectional innovation survey data with longitudinal information on business performance. This will allow us to assess more robustly the causality between innovation and business performance as well as calibrating lags in this connection.

(Annex 1 here) 
Figure 1: The Innovation Value Chain: Structure and Key Indicators
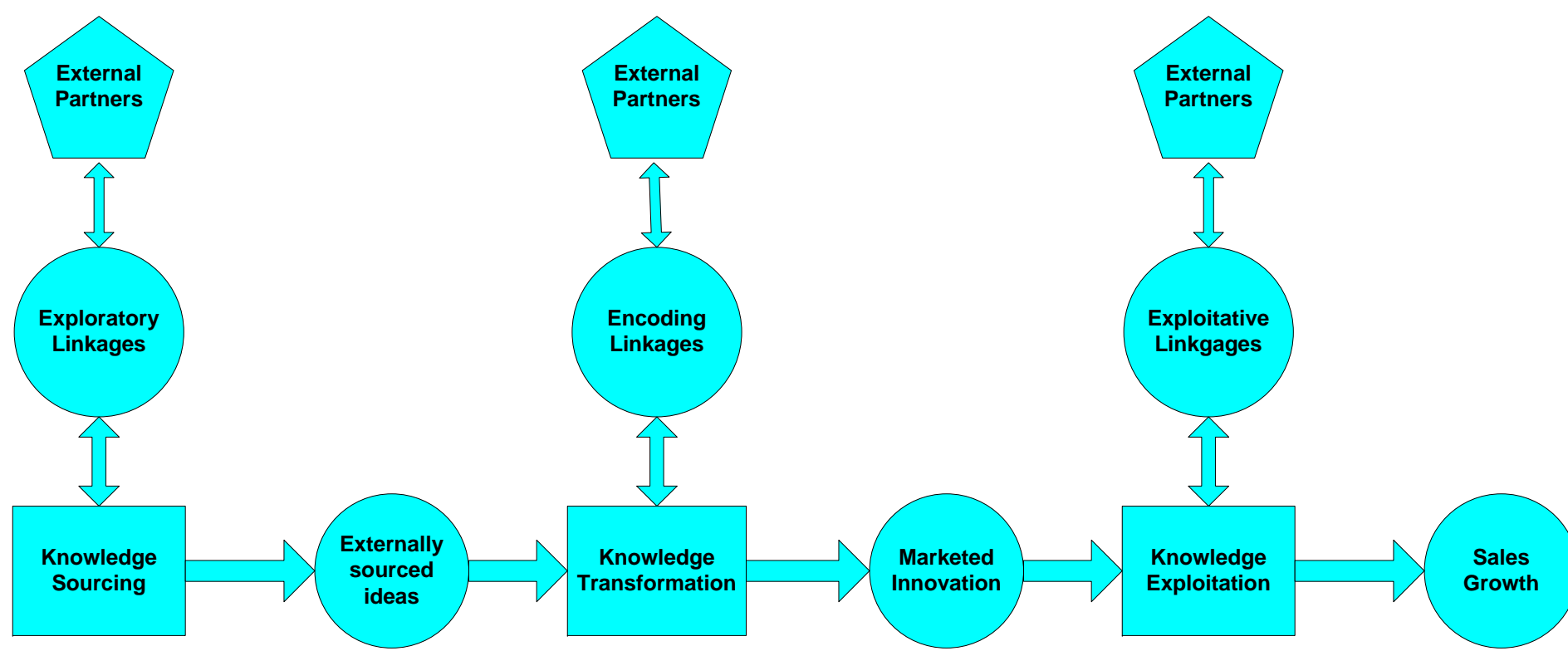

\begin{tabular}{|c|c|c|}
\hline Knowledge sourcing & Knowledge transformation & Knowledge exploitation \\
\hline $\begin{array}{l}\text { Inputs: R\&D investment, Design } \\
\text { investment; Engagement of multi- } \\
\text { functional teams, engagement of } \\
\text { external partners } \\
\text { Output: Externally sourced ideas }\end{array}$ & $\begin{array}{l}\text { Inputs: Externally sourced ideas, } \\
\text { investment in process change, } \\
\text { engagement of multi-functional teams, } \\
\text { engagement of external partners } \\
\text { Outputs: Innovative sales and diversity }\end{array}$ & $\begin{array}{l}\text { Inputs: Innovative sales and diversity, } \\
\text { investment in branding and marketing, } \\
\text { engagement of multi-functional teams, } \\
\text { engagement of external partners. IP } \\
\text { protection, customer partnering } \\
\text { Outputs: Sales growth. }\end{array}$ \\
\hline
\end{tabular}


Figure 2: Profile of Connections to External Organisations: By stage of the IVC

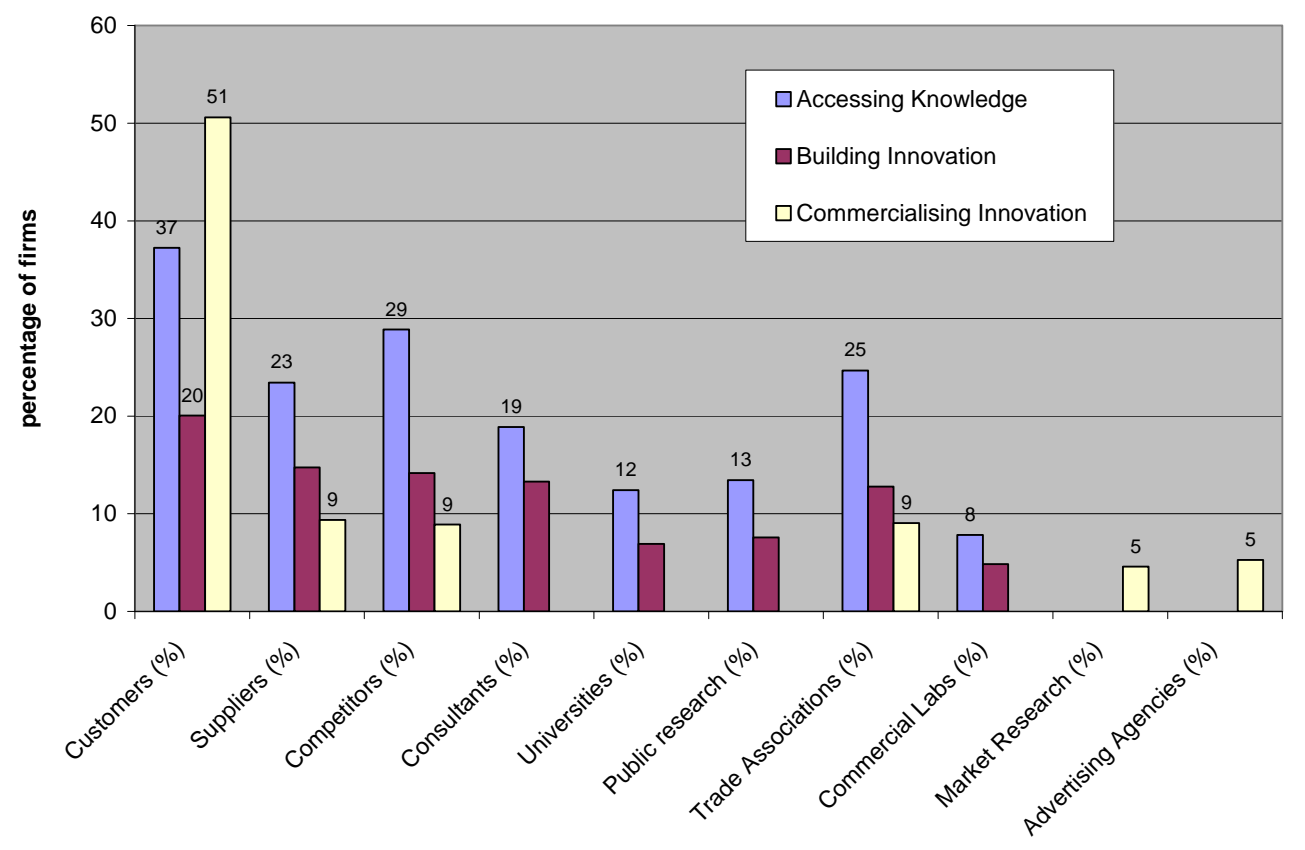


Table 1: Descriptives

\begin{tabular}{|c|c|c|c|c|}
\hline & \multicolumn{2}{|c|}{$\begin{array}{c}\text { Whole sample } \\
\mathrm{N}=\mathrm{c} .1151\end{array}$} & \multicolumn{2}{|c|}{$\begin{array}{l}\text { Estimation sample } \\
\mathrm{N}=\text { c. } 651\end{array}$} \\
\hline & Mean & Std. Dev. & Mean & Std. Dev. \\
\hline \multicolumn{5}{|l|}{ Performance indicators } \\
\hline Service ideas from outside the firm $(\%)$ & 10.94 & 23.50 & 12.56 & 24.44 \\
\hline Innovator in service or business model $(0 / 1)$ & 45.48 & 49.80 & 50.57 & 50.00 \\
\hline Innovative percentage of sales ( $\%$ sales) & 14.44 & 25.16 & 17.35 & 26.95 \\
\hline Diversity of innovation activity $(\%)$ & 32.20 & 29.84 & 35.26 & 29.84 \\
\hline Sales growth (per annum, \%age) & na & na & 9.22 & 41.61 \\
\hline \multicolumn{5}{|l|}{ Input and process indicators } \\
\hline R\&D intensity (\% sales) & na & na & 1.28 & 5.11 \\
\hline Design intensity ( $\%$ sales) & na & na & 1.63 & 5.12 \\
\hline Team working index $(\%)$ & 20.68 & 36.21 & 22.86 & 37.43 \\
\hline Customer interaction index $(\%)$ & 50.62 & 32.22 & 51.87 & 31.82 \\
\hline IP protection index $(\%)$ & 28.97 & 38.46 & 28.78 & 37.43 \\
\hline Firm size (employment, 2009) & 33.96 & 226.19 & 34.03 & 251.77 \\
\hline \multicolumn{5}{|l|}{ Firm and market characteristics } \\
\hline Firm age (years) & 27.28 & 16.80 & 26.87 & 16.77 \\
\hline Single site Firm (\% respondents) & 74.89 & 43.37 & 76.08 & 42.66 \\
\hline Externally-owned firm (\% respondents) & 4.56 & 20.87 & 4.36 & 20.41 \\
\hline Exporting firm (\% respondents) & 43.75 & 49.61 & 43.88 & 49.62 \\
\hline Number of competitors (number) & 11.45 & 5.01 & 11.57 & 4.97 \\
\hline Workforce with degree (\% respondents) & 48.60 & 27.86 & 46.85 & 27.95 \\
\hline \multicolumn{5}{|l|}{ Multifunctional working } \\
\hline For Sourcing Knowledge (\% respondents) & 29.21 & 34.99 & 31.87 & 34.70 \\
\hline For Knowledge Transformation (\% respondents) & 28.72 & 34.04 & 31.26 & 34.06 \\
\hline For Exploiting Innovation (\% respondents) & 22.37 & 29.62 & 24.47 & 30.06 \\
\hline \multicolumn{5}{|l|}{ Public Support } \\
\hline For Sourcing Knowledge (\% respondents) & 8.30 & 27.59 & 9.96 & 29.94 \\
\hline For Knowledge Transformation ( $\%$ respondents) & 5.62 & 23.02 & 7.36 & 26.12 \\
\hline For Exploiting Innovation (\% respondents) & 4.70 & 21.17 & 5.40 & 22.60 \\
\hline \multicolumn{5}{|l|}{ Exploratory Linkages } \\
\hline Customers (\% respondents) & 37.23 & 48.34 & 43.56 & 49.58 \\
\hline Suppliers (\% respondents) & 23.44 & 42.36 & 28.37 & 45.08 \\
\hline Competitors (\% respondents) & 28.85 & 45.31 & 33.49 & 47.20 \\
\hline Consultants (\% respondents) & 18.89 & 39.14 & 20.58 & 40.43 \\
\hline Universities (\% respondents) & 12.43 & 32.99 & 14.36 & 35.07 \\
\hline Public research (\% respondents) & 13.45 & 34.12 & 16.33 & 36.96 \\
\hline Trade Associations ( $\%$ respondents) & 24.67 & 43.11 & 27.35 & 44.58 \\
\hline Commercial Labs (\% respondents) & 7.83 & 26.86 & 9.17 & 28.86 \\
\hline \multicolumn{5}{|l|}{ Encoding Linkages } \\
\hline Customers ( $\%$ respondents) & 20.06 & 40.04 & 23.75 & 42.55 \\
\hline Suppliers (\% respondents) & 14.75 & 35.46 & 17.63 & 38.11 \\
\hline Competitors (\% respondents) & 14.17 & 34.87 & 16.03 & 36.69 \\
\hline Consultants (\% respondents) & 13.29 & 33.94 & 14.96 & 35.66 \\
\hline Universities (\% respondents) & 6.89 & 25.33 & 7.22 & 25.89 \\
\hline Public research (\% respondents) & 7.57 & 26.45 & 8.70 & 28.18 \\
\hline Trade Associations ( $\%$ respondents) & 12.79 & 33.40 & 13.62 & 34.30 \\
\hline Commercial Labs (\% respondents) & 4.85 & 21.49 & 5.45 & 22.70 \\
\hline \multicolumn{5}{|l|}{ Exploitative Linkages } \\
\hline Suppliers (\% respondents) & 9.37 & 29.14 & 10.45 & 30.59 \\
\hline Competitors (\% respondents) & 8.89 & 28.45 & 9.55 & 29.39 \\
\hline Market Research Companies (\% respondents) & 4.57 & 20.89 & 4.29 & 20.27 \\
\hline Advertising Agencies (\% respondents) & 5.27 & 22.35 & 4.81 & 21.40 \\
\hline Professional Associations (\% respondents) & 9.06 & 28.70 & 9.20 & 28.90 \\
\hline
\end{tabular}

Source: UK Innovation Index Survey 2009. Observations are weighted to give representative results. Variable definitions in Annex 1. Whole sample is all respondents. Estimation sample are those respondents providing financial information for which growth models can be estimated. 
Table 2: Sourcing Knowledge: Tobit models of the share of new service ideas from outside the firm

\begin{tabular}{|c|c|c|c|c|}
\hline & Model 1 & Model 2 & Model 3 & Model 4 \\
\hline \multicolumn{5}{|l|}{ Resource Indicators } \\
\hline \multirow[t]{2}{*}{ Firm size (employment) } & 0.012 & 0.01 & 0.001 & 0.003 \\
\hline & $(0.010)$ & $(0.009)$ & $(0.009)$ & $(0.008)$ \\
\hline \multirow[t]{2}{*}{ Firm size squared (empl) } & 0.000 & 0.000 & 0.000 & 0.000 \\
\hline & $(0.000)$ & $(0.000)$ & $(0.000)$ & $(0.000)$ \\
\hline \multirow[t]{2}{*}{ Firm age (years) } & 0.138 & & 0.078 & \\
\hline & $(0.199)$ & & $(0.166)$ & \\
\hline \multirow[t]{2}{*}{ Single-site company } & 3.676 & & -2.67 & \\
\hline & $(7.052)$ & & $(5.819)$ & \\
\hline \multirow[t]{2}{*}{ Externally-owned firm } & -5.414 & & 0.32 & \\
\hline & $(15.038)$ & & (12.174) & \\
\hline \multirow[t]{2}{*}{ Exporting firm } & 11.033 & 10.802 & 1.32 & 1.586 \\
\hline & $(6.889)$ & $(6.875)$ & $(5.635)$ & $(5.572)$ \\
\hline \multirow[t]{2}{*}{ Number of competitors } & 0.581 & 0.632 & 0.316 & 0.322 \\
\hline & $(0.649)$ & $(0.650)$ & $(0.546)$ & $(0.541)$ \\
\hline \multirow[t]{2}{*}{ Workforce with degree $(\%)$} & 0.063 & 0.052 & 0.06 & 0.051 \\
\hline & $(0.114)$ & $(0.111)$ & $(0.094)$ & $(0.091)$ \\
\hline \multirow[t]{2}{*}{ Public support: Sourcing K. } & 9.966 & 9.868 & $12.943^{*}$ & 12.555 \\
\hline & $(9.439)$ & $(9.329)$ & $(7.729)$ & $(7.684)$ \\
\hline \multirow[t]{2}{*}{ Multifunctionality: Scg. K. } & $0.223 * *$ & $0.230 * *$ & $0.324 * * *$ & $0.326 * * *$ \\
\hline & $(0.095)$ & $(0.094)$ & $(0.084)$ & $(0.084)$ \\
\hline \multicolumn{5}{|l|}{ Internal knowledge } \\
\hline \multirow[t]{2}{*}{$\mathrm{R} \& \mathrm{D}$ Intensity } & -0.184 & -0.207 & & \\
\hline & $(0.631)$ & $(0.632)$ & & \\
\hline \multirow[t]{2}{*}{ Design Intensity } & $1.071 *$ & $1.076^{*}$ & & \\
\hline & $(0.652)$ & $(0.651)$ & & \\
\hline \multirow[t]{2}{*}{$R \& D$ in house $(0 / 1)$} & & & 6.501 & 6.526 \\
\hline & & & $(6.959)$ & $(7.002)$ \\
\hline \multirow[t]{2}{*}{ Design in house $(0 / 1)$} & & & $12.653 * *$ & $12.694 * *$ \\
\hline & & & $(6.236)$ & $(6.269)$ \\
\hline External knowledge seeking & & & & \\
\hline \multirow[t]{2}{*}{ Interaction: Customers } & $27.935 * *$ & $27.766^{* *}$ & $32.411 * * *$ & $32.226 * * *$ \\
\hline & $(12.363)$ & $(12.373)$ & $(11.361)$ & $(11.321)$ \\
\hline \multirow[t]{2}{*}{ Interaction: Suppliers } & 1.514 & 1.403 & -5.177 & -5.584 \\
\hline & $(8.480)$ & $(8.465)$ & $(7.333)$ & $(7.208)$ \\
\hline \multirow[t]{2}{*}{ Interaction: Competitors } & 2.322 & 2.54 & 3.785 & 4.026 \\
\hline & $(10.674)$ & $(10.598)$ & $(9.406)$ & $(9.393)$ \\
\hline \multirow[t]{2}{*}{ Interaction: Consultants } & 10.811 & 10.526 & 7.397 & 7.645 \\
\hline & $(8.511)$ & $(8.551)$ & $(7.410)$ & $(7.410)$ \\
\hline Interaction: Universities & 5.922 & 5.554 & 2.747 & 2.736 \\
\hline & $(8.934)$ & $(9.018)$ & $(8.133)$ & $(8.074)$ \\
\hline Interaction: Public Research & -4.067 & -4.053 & -4.765 & -4.523 \\
\hline & $(10.489)$ & $(10.460)$ & $(8.950)$ & $(8.923)$ \\
\hline Interaction: Trade & -2.663 & -2.535 & -1.352 & -0.876 \\
\hline & $(9.676)$ & $(9.675)$ & $(8.312)$ & $(8.232)$ \\
\hline Interaction: Commercial Labs & -1.878 & -2.986 & -1.383 & -1.517 \\
\hline & $(10.457)$ & $(10.291)$ & $(9.463)$ & $(9.358)$ \\
\hline Number of observations & 578 & 578 & 930 & 930 \\
\hline $\mathrm{F}(.)$. & 5.84 & 6.61 & 9.25 & 10.45 \\
\hline $\mathrm{P}$ & 0.000 & 0.000 & 0.000 & 0.000 \\
\hline Pseudo $\mathrm{R}^{2}$ & 0.058 & 0.058 & 0.065 & 0.065 \\
\hline
\end{tabular}

Source: Innovation Index Survey 2009. Observations are weighted to give representative results. Variable definitions in Annex 1. Models contained industry dummy variables and constant term. Marginal effects are reported. . * denotes significance at the 10 per cent level; ** at 5 per cent and $* * *$ at the 1 per cent level. 
Table 3: Transforming Knowledge: Tobit Models of Innovative Sales and the Diversity of Innovation

\begin{tabular}{|c|c|c|c|c|}
\hline & \multicolumn{2}{|c|}{ Percentage of innovative sales } & \multicolumn{2}{|c|}{ Diversity of innovation } \\
\hline & Model 1 & Model 2 & Model 3 & Model 4 \\
\hline Estimation method & IVTobit & IVTobit & IVTobit & IVTobit \\
\hline \multicolumn{5}{|l|}{ Internal knowledge } \\
\hline \multirow[t]{2}{*}{ R\&D intensity } & 0.138 & 0.164 & 0.457 & 0.44 \\
\hline & $(0.603)$ & $(0.611)$ & $(0.647)$ & $(0.643)$ \\
\hline \multirow[t]{2}{*}{ Design intensity } & 0.939 & 0.907 & -0.672 & -0.67 \\
\hline & $(0.823)$ & $(0.844)$ & $(0.793)$ & $(0.819)$ \\
\hline \multirow[t]{2}{*}{ Externally sourced ideas } & 1.093 & 1.279 & $1.657 * *$ & $1.699 * *$ \\
\hline & $(0.849)$ & $(0.932)$ & $(0.763)$ & $(0.754)$ \\
\hline \multicolumn{5}{|l|}{ Firm Resources } \\
\hline \multirow[t]{2}{*}{ Firm size (employment) } & 0.011 & 0.014 & $0.019 * *$ & $0.018 * *$ \\
\hline & $(0.011)$ & $(0.009)$ & $(0.010)$ & $(0.009)$ \\
\hline \multirow[t]{2}{*}{ Firm size squared (empl) } & 0.000 & 0.000 & 0.000 & 0.000 \\
\hline & $(0.000)$ & $(0.000)$ & $(0.000)$ & $(0.000)$ \\
\hline \multirow[t]{2}{*}{ Firm age (years) } & -0.196 & & -0.186 & -0.201 \\
\hline & $(0.159)$ & & $(0.147)$ & $(0.148)$ \\
\hline \multirow[t]{2}{*}{ Single-site company } & -4.694 & & $-10.155^{*}$ & $-10.294 *$ \\
\hline & $(5.683)$ & & $(5.605)$ & $(5.734)$ \\
\hline \multirow[t]{2}{*}{ Externally-owned firm } & -15.097 & -9.32 & 1.056 & 2.272 \\
\hline & $(14.732)$ & $(14.982)$ & $(12.339)$ & $(12.197)$ \\
\hline \multirow[t]{2}{*}{ Exporting firm } & 5.838 & & 0.094 & \\
\hline & $(5.593)$ & & $(4.994)$ & \\
\hline \multirow[t]{2}{*}{ Number of competitors } & $-1.161 * *$ & $-1.168 * *$ & -0.247 & \\
\hline & $(0.540)$ & $(0.520)$ & $(0.468)$ & \\
\hline \multirow[t]{2}{*}{ Workforce with degree $(\%)$} & -0.13 & & $-0.135 *$ & $-0.140 *$ \\
\hline & $(0.092)$ & & $(0.081)$ & $(0.081)$ \\
\hline \multirow[t]{2}{*}{ Public support: Transforming K. } & $12.613^{*}$ & $16.159 * *$ & 13.804 & 14.306 \\
\hline & $(7.244)$ & $(7.214)$ & $(8.626)$ & $(8.746)$ \\
\hline \multirow[t]{2}{*}{ Multifunctionality: Trans K. } & $0.302 * * *$ & $0.289 * *$ & 0.13 & 0.126 \\
\hline & $(0.112)$ & $(0.124)$ & $(0.113)$ & $(0.112)$ \\
\hline \multirow[t]{2}{*}{ Team working index } & $0.176^{* *}$ & $0.164 * *$ & $0.174 * *$ & $0.172 * *$ \\
\hline & $(0.077)$ & $(0.076)$ & $(0.076)$ & $(0.077)$ \\
\hline \multicolumn{5}{|l|}{ External Connectivity } \\
\hline Interaction: Customers & -1.946 & -7.82 & 0.056 & -0.079 \\
\hline & $(14.801)$ & $(17.178)$ & $(10.053)$ & $(9.850)$ \\
\hline Interaction: Suppliers & 17.901 & 20.482 & 10.749 & 11.159 \\
\hline & $(11.761)$ & $(12.941)$ & $(9.962)$ & $(9.702)$ \\
\hline Interaction: Competitors & -17.778 & -18.209 & -8.978 & -9.26 \\
\hline & $(13.334)$ & $(13.618)$ & $(12.267)$ & $(12.420)$ \\
\hline Interaction: Consultants & 7.291 & 11.054 & 4.143 & 4.346 \\
\hline & $(9.729)$ & $(10.421)$ & $(9.173)$ & $(9.258)$ \\
\hline Interaction: Universities & -11.383 & -11.471 & -6.191 & -6.665 \\
\hline & $(10.330)$ & $(10.736)$ & $(9.291)$ & $(9.441)$ \\
\hline Interaction: Public Research & 5.752 & 5.674 & $29.287 * * *$ & $29.842 * * *$ \\
\hline & $(11.733)$ & $(11.692)$ & $(10.427)$ & $(10.557)$ \\
\hline Interaction: Trade Associations & -7.754 & -7.316 & -10.122 & -10.644 \\
\hline & $(10.747)$ & $(10.143)$ & $(12.277)$ & $(12.882)$ \\
\hline Interaction: Commercial Labs & 17.748 & $22.851 *$ & 8.286 & 8.821 \\
\hline & $(13.435)$ & $(13.870)$ & $(11.556)$ & (11.483) \\
\hline Number of observations & 564 & 597 & 570 & 579 \\
\hline & 157.081 & 157.32 & 237.528 & 232.644 \\
\hline Equation $\chi^{2}$ & $(\rho<0.000)$ & $(\rho<0.000)$ & $(\rho<0.000)$ & $(\rho<0.000)$ \\
\hline & 2.15 & 2.99 & 3.68 & 3.56 \\
\hline Amemiya-Lee-Newey test & $(\rho=0.34)$ & $(\rho=0.22)$ & $(\rho=0.16)$ & $(\rho=0.17)$ \\
\hline
\end{tabular}

Source: Innovation Index Survey 2009. Observations are weighted to give representative results. Variable definitions in Annex 1. Models contained industry dummy variables and constant term. * denotes significance at the 10 per cent level; ** at 5 per cent and $* * *$ at the 1 per cent level. 
Table 4: Exploiting Innovation: OLS Modelling Three-year Sales Growth

\begin{tabular}{|c|c|c|c|c|c|}
\hline & $\begin{array}{r}\text { Model } 1 \\
\mathrm{~b} / \mathrm{se}\end{array}$ & $\begin{array}{r}\text { Model } 2 \\
\mathrm{~b} / \mathrm{se}\end{array}$ & $\begin{array}{r}\text { Model } 3 \\
\mathrm{~b} / \mathrm{se}\end{array}$ & $\begin{array}{r}\text { Model } 4 \\
\mathrm{~b} / \mathrm{se} \\
\end{array}$ & $\begin{array}{r}\text { Model } 5 \\
\mathrm{~b} / \mathrm{se}\end{array}$ \\
\hline Firm characteristics & & & & & \\
\hline Firm size (employment) & $\begin{array}{r}0.000 * * * \\
(0.000)\end{array}$ & $\begin{array}{r}0.000 * * * \\
(0.000)\end{array}$ & $\begin{array}{r}0.000 * * * \\
(0.000)\end{array}$ & $\begin{array}{r}0.000 * * * \\
(0.000)\end{array}$ & $\begin{array}{r}0.000 * * * \\
(0.000)\end{array}$ \\
\hline Firm size squared (empl) & $\begin{array}{r}-0.000 * * * \\
(0.000)\end{array}$ & $\begin{array}{r}-0.000 * * * \\
(0.000)\end{array}$ & $\begin{array}{r}-0.000 * * * \\
(0.000)\end{array}$ & $\begin{array}{r}-0.000 * * * \\
(0.000)\end{array}$ & $\begin{array}{r}-0.000 * * * \\
(0.000)\end{array}$ \\
\hline Firm age (years) & $\begin{array}{r}-0.005^{* * *} \\
(0.002)\end{array}$ & $\begin{array}{r}-00.004 * * * \\
(0.002)\end{array}$ & $\begin{array}{r}-0.004 * * * \\
(0.002)\end{array}$ & $\begin{array}{r}-0.005 * * * \\
(0.002)\end{array}$ & $\begin{array}{r}-0.005 * * * \\
(0.002)\end{array}$ \\
\hline Externally-owned firm & $\begin{array}{r}0.054 \\
(0.110)\end{array}$ & $\begin{array}{r}0.09 \\
(0.112)\end{array}$ & & $\begin{array}{r}0.051 \\
(0.108)\end{array}$ & \\
\hline Public support: Commercialis. & $\begin{array}{r}0.129 \\
(0.108)\end{array}$ & $\begin{array}{r}0.146 \\
(0.103)\end{array}$ & & $\begin{array}{r}0.126 \\
(0.106)\end{array}$ & \\
\hline Multifunctionality & $\begin{array}{r}0.000 \\
(0.001)\end{array}$ & $\begin{array}{r}0.000 \\
(0.001)\end{array}$ & & $\begin{array}{r}0.001 \\
(0.001)\end{array}$ & \\
\hline IP protection index & $\begin{array}{r}0.000 \\
(0.001)\end{array}$ & $\begin{array}{r}-0.001 \\
(0.001)\end{array}$ & $\begin{array}{l}-0.001 \\
(0.001)\end{array}$ & $\begin{array}{l}-0.001 \\
(0.001)\end{array}$ & $\begin{array}{r}0.000 \\
(0.001)\end{array}$ \\
\hline Exporting firm & $\begin{array}{r}0.01 \\
(0.047)\end{array}$ & $\begin{array}{r}0.014 \\
(0.048)\end{array}$ & & $\begin{array}{r}0.011 \\
(0.048)\end{array}$ & \\
\hline Number of competitors & $\begin{array}{r}0.001 \\
(0.005)\end{array}$ & $\begin{array}{r}0.002 \\
(0.005)\end{array}$ & & $\begin{array}{r}0.001 \\
(0.005)\end{array}$ & \\
\hline $\begin{array}{l}\text { Innovation Outputs } \\
\text { Innovator }(0 / 1)\end{array}$ & $\begin{array}{r}0.228 * * * \\
(0.065)\end{array}$ & & & & \\
\hline Innovative sales $(\log , \%)$ & & $\begin{array}{r}0.054 * * * \\
(0.019)\end{array}$ & $\begin{array}{r}0.061 * * * \\
(0.017)\end{array}$ & & \\
\hline Diversity of innovation (\%) & & & & $\begin{array}{r}0.002 * * \\
(0.001)\end{array}$ & $\begin{array}{r}0.002 * * * \\
(0.001)\end{array}$ \\
\hline Exploitative Relationships & & & & & \\
\hline Customer interaction index & $\begin{array}{r}0.000 \\
(0.001)\end{array}$ & $\begin{array}{r}0.000 \\
(0.001)\end{array}$ & $\begin{array}{r}0.001 \\
(0.001)\end{array}$ & $\begin{array}{r}0.000 \\
(0.001)\end{array}$ & $\begin{array}{r}0.000 \\
(0.001)\end{array}$ \\
\hline Interaction: Suppliers & $\begin{array}{r}-0.095 \\
(0.077)\end{array}$ & $\begin{array}{r}-0.102 \\
(0.076)\end{array}$ & $\begin{array}{r}-0.095 \\
(0.076)\end{array}$ & $\begin{array}{r}-0.093 \\
(0.072)\end{array}$ & $\begin{array}{r}-0.07 \\
(0.069)\end{array}$ \\
\hline Interaction: Competitors & $\begin{array}{r}-0.062 \\
(0.077)\end{array}$ & $\begin{array}{r}-0.059 \\
(0.074)\end{array}$ & $\begin{array}{r}-0.067 \\
(0.075)\end{array}$ & $\begin{array}{r}-0.052 \\
(0.075)\end{array}$ & $\begin{array}{r}-0.062 \\
(0.074)\end{array}$ \\
\hline Interaction: Market Research & $\begin{array}{l}-0.119 \\
(0.107)\end{array}$ & $\begin{array}{r}-0.134 \\
(0.104)\end{array}$ & $\begin{array}{l}-0.132 \\
(0.102)\end{array}$ & $\begin{array}{r}-0.116 \\
(0.104)\end{array}$ & $\begin{array}{r}-0.111 \\
(0.101)\end{array}$ \\
\hline Interaction: Advertising Agencies & $\begin{array}{r}0.022 \\
(0.099)\end{array}$ & $\begin{array}{r}-0.009 \\
(0.099)\end{array}$ & $\begin{array}{r}0.012 \\
(0.098)\end{array}$ & $\begin{array}{r}0.008 \\
(0.098)\end{array}$ & $\begin{array}{r}0.022 \\
(0.096)\end{array}$ \\
\hline Interaction: Professional & $0.164^{*}$ & $0.198 * *$ & $0.203 * *$ & $0.161^{*}$ & $0.161 *$ \\
\hline & $(0.091)$ & $(0.090)$ & $(0.087)$ & $(0.089)$ & $(0.089)$ \\
\hline Constant term & $\begin{array}{r}-0.043 \\
(0.118)\end{array}$ & $\begin{array}{r}0.005 \\
(0.110)\end{array}$ & $\begin{array}{l}-0.001 \\
(0.110)\end{array}$ & $\begin{array}{r}0.018 \\
(0.111)\end{array}$ & $\begin{array}{r}0.004 \\
(0.115)\end{array}$ \\
\hline Number of observations & 589 & 581 & 604 & 589 & 615 \\
\hline $\mathrm{F}(.)$. & 3.71 & 3.73 & 4.68 & 3.82 & 4.63 \\
\hline $\mathrm{P}$ & 0.000 & 0.000 & 0.000 & 0.000 & 0.000 \\
\hline Pseudo $\mathrm{R}^{2}$ & 0.109 & 0.104 & 0.102 & 0.0915 & 0.0837 \\
\hline
\end{tabular}

Source: Innovation Index Survey 2009. Observations are weighted to give representative results. Variable definitions in Annex 1. Models contained industry dummy variables and constant term. * denotes significance at the 10 per cent level; $* *$ at 5 per cent and $* * *$ at the 1 per cent level. 


\begin{tabular}{|c|c|}
\hline Performance indicators & \\
\hline $\begin{array}{l}\text { Service ideas from outside the firm } \\
(\%)\end{array}$ & $\begin{array}{l}\text { Proportion of new products or service ideas } \\
\text { developed outside the firm at the time of the } \\
\text { survey }\end{array}$ \\
\hline $\begin{array}{l}\text { Innovator in service or business } \\
\text { model }(0 / 1)\end{array}$ & $\begin{array}{l}\text { Dummy variable taking value } 1 \text { if the firm } \\
\text { engaged in service or business process } \\
\text { innovation during the previous three years }\end{array}$ \\
\hline $\begin{array}{l}\text { Innovative percentage of sales }(\% \\
\text { sales) }\end{array}$ & $\begin{array}{l}\text { Percentage of firms' sales derived from new } \\
\text { or improved products or services over the last } \\
\text { three years }\end{array}$ \\
\hline Diversity of innovation activity (\%) & $\begin{array}{l}\text { An index which takes value } 100 \text { if a firm } \\
\text { engaged in all six types of innovation activity } \\
\text { (i.e. service, business process, managerial, } \\
\text { strategic, marketing and organizational), } 50 \text { if } \\
\text { the firm undertook three different forms of } \\
\text { innovation etc }\end{array}$ \\
\hline Sales growth (three year, \%age) & Sales growth over the $2006-09$ period (\%) \\
\hline Input and process indicators & \\
\hline R\&D intensity (\% sales) & $\begin{array}{l}\text { R\&D expenditure as a percentage of sales in } \\
2009\end{array}$ \\
\hline Design intensity (\% sales) & $\begin{array}{l}\text { Design expenditure as a percentage of sales in } \\
2009\end{array}$ \\
\hline Team working index $(\%)$ & $\begin{array}{l}\text { An index taking value } 100 \text { if firms agreed } \\
\text { with five statements on the importance of } \\
\text { team working in the firm (and proportionately } \\
\text { otherwise): team working plays a major role } \\
\text { in the development of services and business } \\
\text { processes; our development teams are cross- } \\
\text { functional and involve people from different } \\
\text { parts of the firm; teams operate very } \\
\text { independently and are left to get on with } \\
\text { solving the problem; our firm invests in } \\
\text { training in team working; our teams often } \\
\text { involve customers or suppliers. }\end{array}$ \\
\hline Customer interaction index $(\%)$ & $\begin{array}{l}\text { An index taking value } 100 \text { if firms use all } \\
\text { forms of customer interaction identified (and } \\
\text { proportionately otherwise): involve customers } \\
\text { in service evaluation and development; } \\
\text { monitor customer feedback to shape new } \\
\text { product and services; use structured CRM } \\
\text { systems or approaches; hold regular customer } \\
\text { seminars or workshops on new services; } \\
\text { develop customer-specific solutions. }\end{array}$ \\
\hline IP protection index $(\%)$ & An index taking value 100 if firms regards all \\
\hline
\end{tabular}


Firm size (employment)

Firm and market characteristics

Firm age (years)

Single site Firm $(\%)$

Externally-owned firm (\%)

Exporting firm (\%)

Number of competitors (number)

Workforce with degree (\%)

Multi-functional working

\section{Public Support}

For Accessing Knowledge (\%)

For Building Innovation (\%)

For Exploiting Innovation (\%)

\section{Exploratory/Encoding/Exploitation links}

Customers (\%), suppliers, competitors, consultants, universities, public research groups, trade associations, commercial labs forms of IP protection identified as important or very important (and proportionately otherwise): registration of new designs; trademarks; patent protection; copyrights; confidentiality agreements; employee nondisclosure agreements.

Firm employment in 2006

Firm age in years

Dummy variable taking value 1 if the firm is a single site (rather than multi-site) business Dummy variable taking value 1 if the firm is wholly owned from outside the UK.

Dummy variable taking value 1 if the firm is exporting.

The number of competitors the firm faces in its main markets.

Percentage of the firms' workforce with a degree level qualification.

An index taking value 100 if firms use all skill groups identified (and proportionately otherwise). Typical skills groups were: directors/partners, other project or management staff; supervisors, technical or clerical staff, administrative staff, marketing staff. Skill groups identified differ somewhat between sectors.

Dummy variable taking value 1 if the firm received public support (from local, national or EU sources) to support its knowledge sourcing activities.

Dummy variable taking value 1 if the firm received public support (from local, national or EU sources) to support its innovation activity.

Dummy variable taking value 1 if the firm received public support (from local, national or EU sources) to support its commercialisation activity.

A dummy variable taking value 1 if the firm has links to customers as part of its knowledge sourcing/ building innovation/ commercialisation activities. Similar measures for other types of partner. 


\section{References}

Agarwal, R., and W. Selen. 2009. Dynamic Capability Building in Service Value Networks for Achieving Service Innovation. Decision Sciences 40 (3):431-475. Amemiya T (1978) The estimation of a simultaneous equation generalized probit model. Econometrica 46(5): 1193-1205.

Anand, N., Gardner, H.K., Morris, T. 2007. Knowledge-based innovation: Emergence and embedding of new practice areas in management consulting firms, Academy of Management Journal 50(2) 406-428.

Baker, P. (2007), 'The impact of business-services use on client industries: evidence from input-output data', in Rubalcaba L., and Kok H. (eds.) Business services in European Economic Growth" Palgrave MacMillan: 97-115

Barkham, R, G Gudgin, M Hart, and E Hanvey. 1996. The Determinants of Small Firm Growth: an inter-regional study in the UK 1986-90. London: Jessica Kingsley.

Baum, C.F., Schaffer, M.E., Stillman, S., Wiggins, V. 2006. overid: Stata module to calculate tests of over identifying restrictions after ivreg, ivreg2, ivprobit, ivtobit, reg3. http://ideas.repec.org/c/boc/bocode/s396802.html

Bessant, J., and H. Rush. 1995. Building Bridges for Innovation - The Role Of Consultants In Technology-Transfer. Research Policy 24 (1):97-114.

Beugelsdijck, P J, and M Cornet. 2001. How far do they reach? The localisation of industrial and academic spillovers in the Netherlands. Centre discussion paper (2001):47.

Blind, K, and A Jungmittag. 2004. Foreign direct investment, imports and innovations in the service industry. Review of Industrial Organisation 25:205-227.

Bryson, J.R. 2007. A 'Second' Global Shift? The Offshoring or Global Sourcing of Corporate Services and the Rise of Distanciated Emotional Labour, Geografiska Annaler 89B (S1): 31-43.

Bryson, J.R. 2010. 'Service Innovation and Manufacturing Innovation: Bundling and Blending Services and Products in Hybrid Production Systems to Produce Hybrid Products', in Gallouj F. \& Djellal, F. (Ed), Handbook on Innovation in Services, Edward Elgar: Cheltenham: 679-700.

Bryson J.R. 2010. Hybrid Manufacturing Systems and Hybrid Products: Services, Production and Industrialisation, Auflage, Aachen \& LuLu-Verlag

Bryson, J.R. and Daniels, P.W. 2008. Skills, Expertise and Innovation in the Developing Knowledge Economy: The Case of Business and Professional Services, International Journal of Services Technology and Management, 9: 3/4: 249267.

Bryson, J.R. and Daniels, P.W. 2010. Service Worlds: The 'Services Duality' and the Rise of the 'Manuservice' Economy, in Maglio, P. Kieliszewski, C. and Spohrer, J.C. (eds), The Handbook of Service Science, Springer: Berlin 79106.

Buiseret, T, H M Cameron, and L Georgiou. 1995. What differences does it make?

Additionality in the public support of R\&D in large firms. International Journal Of Technology Management 10 (4-6):587-600.

Cainelli, G, R Evangelista, and M Savona. 2006. Innovation and Economic performance in services: a firm-level analysis. Cambridge Journal Of Economics 30:435-458.

Callon M., Laredo P., Rabeha V., 1997. Que signifie innover dans les services ? Une triple rupture avec le modèle de l'innovation industrielle, La Recherche, 295: 3436. 
Cameron A C and Trivedi P K (1997) Microeconometrics : Methods and Applications. Cambridge : Cambridge University Press.

Candi, M, and R J Saemundsson. 2008. How different? Comparing the use of design in service innovation in Nordic and American new technology-based firms. Design Studies 29 (5):478-499.

Cassiman, B , and R Veugelers. 2002. Complementarity in the Innovation strategy: Internal R\&D, External technology acquisition and co-operation in R\&D. In EARIE Annual Conference. Madrid.

Cassiman, B, and R Veugelers. 2002. R\&D cooperation and spillovers: some empirial evidence from Belgium The American Economic Review 92 (4):1169-1184.

Chesbrough, H W. 2006. Open Innovation: a new paradigm for understanding industrial innovation. Edited by H. W. Chesbrough, W. Vanhaverbeke and J. West, Open Innovation: researching a new paradigm. Oxford: Oxford University Press.

Chesbrough, H. W. 2003. The era of open innovation. MIT Sloan Management Review 44 (3):35-41.

Chesbrough, H. and Davies, A. 2010. Advancing Service Innovation', in Maglio, P. Kieliszewski, C.A., Spohrer, J.C. (eds), Handbook of Service Science, Springer: New York: 579-601.

Cooper, R.G. and Edgett, S.J. 1996. Critical success factors for new financial services, Marketing Management 5:3: 26-37.

Cooper, R G Kleinschmidt. E. J. (1995). Benchmarking for firm's critical success factors in new product development. Journal of Product Innovation Management, 12 374-391.

Creed, D W E, and R E Miles. 1996. Trust in organizations: a conceptual framework linking organizational forms, managerial philosophies, and the opportunity costs of controls. In Trust in Organizations: Frontiers of Theory and Research, edited by R. M. Kramer and T. R. Tyler. Thousand Oaks: Sage.

Crépon, B., Duguet, E., Mairesse, J., 1998. Research, Innovation and Productivity: An econometric analysis at the firm level. Economics of Inovation and New Technology 7, 115-158.

Cressy, R. 2006. Determinants of small firm growth and survival. In Oxford Handbook of Entrepreneurship edited by M. Casson, B. Yeung, A. Basu and N. Wadeson. Oxford: Oxford University Press.

Czarnitzki, D , and A Spielkamp. 2003. Business services in Germany: Bridges for innovation. The Service Industries Journal 23 (2):1-30.

Daniels, P.W. and Bryson, J.R. 2002. Manufacturing Services and Servicing Manufacturing: changing forms of production in advanced capitalist economies, Urban Studies, 39 (5-6): 977- 991.

Del Barrio-Castro, T., and J. Garcia-Quevedo. 2005. Effects of university research on the geography of innovation. Regional Studies 39 (9):1217-1229.

Dunphy, D , D Turner, and M Crawford. 1997. Organisational learning as the creation of corporate competencies. Journal of Management Development 16 (4):232244.

Edquist, C. 2004. Systems of Innovation - A Critical Review of The State of the Art. Edited by J. Fagerberg, D. Mowery and R. Nelson, Handbook of Innovation: Oxford University Press.

Edquist, C, and L Hommen. 2008. Small Country Innovation Systems - Globalization, Change and Policy in Asia and Europe. Cheltenham Edward Elgar. 
Edvardsson, B. Gustafsson, A. Kristensson, P., Magnusson, P. \& Matthing, J. (Eds). 2001. Involving Customers in New Service Development, Imperial College Press: London.

Edvardsson, B., Gustafsson, A., Krietensson, P. and Witell, L. 2010. Customer integration in service innovation, in Gallouj F. \& Djellal, F. (Eds), Handbook on Innovation in Services, Edward Elgar: Cheltenham: 301-317.

Evans, D. 1987. The relationship between firm growth, size and age: Estimates for 100 manufacturing industries. Journal of Industrial Economics 35, :567-581.

Falk, R. 2004. Behavioural Additionality effects of R\&D Subsidies: Austrian Institute of Economic Research.

Feller, J., A. Parhankangas, and R. Smeds. 2009. Inter-partner relationship, knowledge transfer mechanisms, and improved capability to manage R\&D alliances: evidence from the telecommunications industry. International Journal of Technology Management 47 (4):346-370.

Forfas. 2005. Making Technology Work - A Study of the Absorptive Capacity of Irish SMEs. Dublin.

Freel, M S. 2005. Patterns of Innovation and skills in small firms. Technovation 25:123134.

Fuglsang, L. (ed). 2008. Innovation and the Creative Process: Towards Innovation with Care, Edward Elgar: Cheltenham.

Gallouj, F., 2002. Innovation in the Service Economy: The New Wealth of Nations, Cheltenham: Edward Elgar.

Gallouj F. \& Djellal, F. (Eds). 2010. Handbook on Innovation in Services, Edward Elgar: Cheltenham.

Gallouj, F. and Savona, M. 2010. 'Towards a theory of innovation in services: a state of the art', in Gallouj F. \& Djellal, F. (Eds), Handbook on Innovation in Services, Edward Elgar: Cheltenham: 27-48.

Geroski, P A. 1990. Innovation, Technological Opportunities and Market Structure. Oxford Economic Papers 42:586-602.

Gourlay, A, J Seaton, and J Suppakitjarak. 2005. The determinants of export behaviour in UK service firms. Service Industries Journal 25:879-889.

Grabher, G. 2001. Locating economic action: projects, networks, localities, institutions, introductory notes for the workshop,. In Beyond the Firm? Spatial and Social Dynamics of Project-Organization. Bonn.

Grabher, G (2001) Locating economic action: projects, networks, localities, institutions, introductory notes for the workshop, Beyond the Firm? Spatial and Social Dynamics of Project-Organization, Bonn, April.

Grabher, G. 2002. The product ecology of advertising: Tasks, talents and teams, Regional Studies 36, 245-62.

Grabher, G. 2004, Temporary Architectures of Learning: Knowledge Governance in Project Ecologies. Organization Studies, 25: 9: 1491-1514.

Griffith, R, S Redding, and J Van Reenan. 2003. R\&D and Absorptive Capacity: Theory and Empirical Evidence. Scandinavian Journal of Economics 105 (1):99-118.

Griliches, Z. 1992. The Search for Research-And-Development Spillovers. Scandinavian Journal of Economics 94:S29-S47.

Greenwood, R. Li., X., Prakish, R. and Deephouse, D.L. 2005. Reputation, Diversification, and Organizational Explanations of Performance in Professional Service Firms, Organization Science 16: 6: 661-673. 
Guellec, D, and B van Pottelsberghe. 2004. From R\&D to productivity growth: do the institutional settings and the source of funds matter? Oxford Bulletin of Economics and Statistics 66:353-378.

Gupta, A K and Wilemon, D (1996) 'Changing patterns in industrial R\&D management', Journal of Product Innovation Management, 13, 497- 511.

Hamilton, O., D. Shapiro, and A. Vining. 2002. The growth patterns of Canadian hightech firms. International Journal Of Technology Management 24 (4):458-472.

Hansen, M T, and J Birkinshaw. 2007. The Innovation Value Chain. Harvard Business Review June 121-130.

Hemphill, T A. 2003. Cooperative strategy, Technology Innovation and Product Development in Industrial Companies. International Journal of Production Economics 69 (2):169-176.

Hertog, den P. 2010. Managing Service Innovation: Firm-Level Dynamic Capabilities and Policy Options, Dialogic Innovatie \& Interactie: Utrecht.

Hewitt-Dundas, N , and S Roper. 2009. Output Additionality of Public Support for Innovation: Evidence for Irish Manufacturing Plants. European Planning Studies forthcoming.

Hipp, C. 1999. 'The role of knowledge-intensive business services in the new mode of knowledge production', AI and Society 13:1: 88-106.

Hipp, C. 2010. 'Collaborative Innovation in Services', in Gallouj, F. and Djellal, F. (Eds), The Handbook of Innovation and Services: A multi-disciplinary Perspective, Edward Elgar: Cheltenham: 318-341.

Hipp, C., Tether, B. and Miles, I. 2000. The Incidence and Effects of Innovation in Services: Evidence from Germany. International Journal of Innovation Management 4:2: 417-453.

Horn, Paul M. 2005. The Changing Nature of Innovation. Research Technology Management 48 (6):28-33.

Howells, J., 2000, The Nature of Innovation in Services, Report presented to the OECD Innovation and Productivity Workshop, Sydney, Australia, October

Howells, J., Tether, B.S. and Uyarra, E. 2007. 'Innovation in Business Services: From technological Adoption to Multiple, Complementary, Concurrent Changes', in Rubalcaba L., and Kok H. (eds.) Business services in European Economic Growth" Palgrave MacMillan: 144-162.

IfM and IBM. 2008. Succeeding through service innovation: A service perspective for education, research, business and government, Cambridge, United Kingdom: University of Cambridge Institute for Manufacturing.

Joshi, A W, and S Sharma. 2004. Customer Knowledge Development: Antecedents and Impact on New Product Performance. Journal of Marketing 68 (4):47-59.

Klette, T. J, J Moen, and Z Griliches. 2000. Do subsidies to commercial R\&D reduce market failures? Microeconometric evaluation studies. Research Policy 29 (45):471-495.

Knockaert, M., D Ucbasaran, M Wright, and B. Clarysse. 2009. How does tacit knowledge transfer influence innovation speed? The case of science based entrepreneurial firms. In Vlerick Leuven Gent Working Paper Series 2009/07.

Lee LF (1992) Amemiya's generalized least squares and tests of over identification in simultaneous equation models with qualitative or limited dependent variables. Econometric Reviews 11(3): 319-328.

Leiponen, Aija. 2005. Skills and innovation. International Journal of Industrial Organization 23 (5-6):303-323. 
Levinthal, DA, and JG March. 1993. The myopia of learning. Strategic Management Journal (14):95-112.

Link, A N, D Paton, and D S Siegel. 2005. An Econometric Analysis of Trends in Research Joint Venture Activity. Managerial and Decision Economics 26 (2):149-158.

Lööf, H, and A Heshmati. 2001. On the Relationship between Innovation and Performance: A Sensitivity Analysis. Stockholm School of Economics. . 2002. Knowledge capital and performance heterogeneity: A firm level innovation study. International Journal of Production Economics 76:61-85.

Love, J H and M A Mansury. 2007. External Linkages, R\&D and Innovation Performance in US Business Services. Industry and Innovation forthcoming.

Love, J H, and S Roper. 1999. The determinants of innovation: R\&D, technology transfer and networking effects. Review of Industrial Organisation 15 (1):43-64.

Love J H, Roper S and Hewitt-Dundas N (2010) 'Service Innovation, Embeddedness and Business Performance: Evidence from Northern Ireland', Regional Studies, 44, 983-1004

Luukkonen, T. 2000. Additionality of EU Framework Programmes. Research Policy 29:711-724.

Maglio, P. Kieliszewski, C. and Spohrer, J.C. (eds). 2010. The Handbook of Service Science, Springer: Berlin 79-106.

Mansury, M A, and J H Love. 2008. Innovation, productivity and growth in US business services: A firm-level analysis. Technovation 28:52-62.

March, J G. 1991. Exploration and Exploitation in Organisational Learning. Organisation Science 2 (71-115).

Marsili, O, and A Salter. 2006. The Dark Matter of Innovation: Design and Innovative Performance in Dutch Manufacturing. Technology Analysis \& Strategic Management 18 (5):515-534.

Menor, L.J., Takikonda, M.V.\& Sampson, S.E. 2002. New service development: areas for exploitation and exploration. Journal of Operations Management, 20(2): 135157.

Michie, J, and M Sheehan. 2003. Labour market deregulation, 'flexibility' and innovation. Cambridge Journal of Economics 27 (1):123-143.

Mole, K, M Hart, S Roper, and S Saal. 2008. Assessing the Effectiveness of Business Support Services in England: Evidence from a Theory Based Evaluation. International small business journal Forthcoming

Muller, E, and A Zenker. 2001. Business services as actors of knowledge transformation: The role of KIBS in regional and national innovation systems. Research Policy 30 (9):1501-1516.

Nakata C and Im S (2010)' Spurring Cross-Functional Integration for Higher New Product Performance: A Group Effectiveness Perspective' Journal of Product Innovation Management, 27, 554-571.

Newey WK (1987) Efficient estimation of limited dependent variable models with endogeneous explanatory variables. Journal of Econometrics 36(3): 231-250.

OECD. 2006. Government R\&D Funding and Company Behaviour: Measuring Behavioural Additionality. Paris. . 2007. OECD Framework for the Evaluation of SME and Entrepreneurship Policies and Programes, edited by OECD. Paris

Omar, A. A., and A. V. Mohan. 2006. Aspects of inter-organisational networks for developing firm competencies - Preliminary evidence from Malaysia. 2006 Ieee 
International Conference on Management of Innovation and Technology, Vols 1 and 2, Proceedings:258-262.

Pittaway, L, M Robertson, K Munir, D Denyer, and A Neely. 2004. Networking and Innovation: A Systematic Review of the Evidence. International Journal of Management Reviews 5/6 (3/4):137-168.

Potts, J. and Mandeville, T. 2007. Towards an evolutionary theory of innovation and growth in the service economy. Prometheus 25: 2: 147-159.

Roper, S, J Du, and J H Love. 2008. Modelling the Innovation Value Chain. Research Policy 37:961-977.

Roper S, Hales C, Bryson J R and Love J H (2009) Measuring sectoral innovation capability in nine areas of the UK economy, NESTA, London.

Roper, S, and J H Love. 2001. The Determinants of Export Performance: Panel Data Evidence for Irish Manufacturing Plants. In NIERC Working Paper 67. Belfast: NIERC.

Roper, S , J Youtie, P Shapira, and A Fernandez-Ribas. 2008. Knowledge, Capabilities and Manufacturing Innovation: A US-Europe Comparison'. Regional Studies Forthcoming.

Rothaermel, FT , and DL Deeds. 2004. Exploration and exploitation alliances in biotechnology: a system of new product development. Strategic Management Journal 25:201-221.

Rubalcaba, L. and Kox, H. 2007. Business services in European Economic Growth, Palgrave: Basingstoke.

Schmidt, T. 2010. Absorptive Capacity - One Size Fits All? A Firm-Level Analysis of Absorptive Capacity for Different Kinds of Knowledge. Managerial and Decision Economics 31 (1):1-18.

Smith, A. 1977 [1776]. The wealth of nations. Penguin Books, Harmondworth.

Smith, D J, and D Tranfield. 2005. Talented suppliers? Strategic change and innovation in the UK aerospace industry. R\&D Management 35 (1):37-49.

Spohrer, J. and Maglio, P.P. 2008. The Emergence of Service Science: Towards Systematic Service Innovations to accelerate co-creation of value. Production and Operations Management, 17(3), 1-9.

Stevens, E. and Dimitriadis, S. 2005. Managing the new service development process: towards a systemic model. European Journal of Marketing 39:1/2: 175-198

Stoneman, P. (2010), Soft innovations: economics, product aesthetics and the creative industries, Oxford University Press: Oxford

Sundbo, J. 2002. The Service Economy: Standardisation or Customisation?, The Service Industries Journal, 22: 4: 93-116

Sundbo, J. 2010. The toilsome path of service innovation: the effects of the law of low human multi-task capability. in Gallouj, F. and Djellal, F. (Eds), The Handbook of Innovation and Services: A Multi-disciplinary perspective, Edward Elgar: Cheltenham: 279-300

Tether, B. and Tajar, A. 2008. The organisational-cooperation mode of innovation and its prominence amongst European service firms', Research Policy 37:4: 720-739

Tidd, J. and Bodley, K. 2002. The effect of product novelty on the new product development process. RandD Management, 32: 2: 127-1138.

Treasury, HM. 2000. Productivity in the UK: the Evidence and the Government's Approach, edited by H. Treasury.

von Nordenflycht. 2010. What is a professional service firm? Towards a theory and taxonomy of knowledge-intensive firms. Academy of Management Review 35: 1: 155-174. 
Vandermerwe, S. 1993. From Tim Soldiers to Russian Dolls: Creating added value through services, Butterworth-Heinemann: Oxford.

Vinding, L A. 2006. Absorptive Capacity And Innovative Performance: A Human Capital Approach. The Economics of Innovation and New Technology 15 (4/5):507-517.

Wakelin, K. 1998. Innovation and Export Behaviour at the Firm Level. Research Policy 26:829-841.

Whitley, R. 2006. Project-based firms: new organizational form or variations on a theme? Industrial and Corporate Change 15: 1: 77-99.

Wood, P 2005. A service-informed approach to regional innovation - or adaptation? The Service Industries Journal 25 (4):429-445

Zeller, C. 2002. Project teams as means of restructuring research and development in the pharmaceutical industry. Regional studies, 36 (3):275-289. 